\title{
Military Service and Human Capital Accumulation: Evidence from Colonial Punjab
}

\author{
Oliver Vanden Eynde*
}

4 April 2015 (first draft: May 2011)

\begin{abstract}
This paper estimates the impact of military recruitment during World War 1 on human capital accumulation in colonial Punjab. The empirical strategy exploits the exogenous increase in recruitment by the Indian Army during the war. Higher military recruitment is found to be associated with increased literacy at the district-religion level. However, military recruitment grounds did not attract higher investment in public education. Rather, the observed improvement in the human capital stock appears to be driven by the informal acquisition of literacy skills by serving soldiers. While the historical setting of World War 1 is unique, this paper is one of the first papers to provide empirical evidence on the economic effects of military service in a developing country context.
\end{abstract}

${ }^{*}$ Paris School of Economics and Princeton University (Woodrow Wilson School of Public and International Affairs). Email: oliver.vanden.eynde@ens.fr. I would like to thank the Commonwealth War Graves Commission and Peter Holton in particular for making their electronic records available and for answering questions related to this data set. I would like to thank Gerard Padro-i-Miquel, Jenny Aker, Raj Arunchalam, Oriana Bandiera, Robin Burgess, Guilhem Cassan, Latika Chaudhary, Denis Cogneau, James Fenske, Adnan Khan, Radha Iyengar, Saumitra Jha, Alex Moradi, Ronny Razin, Prakarsh Singh, and Hans-Joachim Voth for helpful discussions and comments. I also benefited from comments by seminar participants at LSE, the Paris School of Economics, FUNDP Namur, PACDEV, the Economic History Society Annual Conference, MWIEDC and IAE (Barcelona). All remaining errors are mine. 


\section{Introduction}

At the outbreak of World War 1, the British Government quickly turned to the Indian Army as a formidable source of man power. The province of Punjab ${ }^{1}$ had become the Indian Army's preferred recruitment area well before 1914, but the war massively increased demand for military forces. The number of men recruited from Punjab increased by a factor of more than 5 between 1914 and 1918. In total, more than 400,000 men (or $1.8 \%$ of the Punjabi population) served in the army during the war. The experience of serving in the army transformed both recruits and their communities. Most Indian soldiers were volunteers recruited from small rural villages and could not read or write before they joined the army. At least for a subset of soldiers, serving in a professional army could have provided opportunities to acquire new skills such as literacy. This paper uses variation in religion-specific regional recruitment rates to assess whether military service in colonial Punjab can explain changes in literacy after the First World War.

Identifying the labor market and educational returns to military service is a well-researched topic for developed countries. The military is typically one of the largest employers (WDI, 2006), so military recruitment policies could have important redistributive effects. In particular, voluntary military service in professional armed forces could offer educational opportunities to disadvantaged groups. ${ }^{2}$ Army service requires most recruits to live in military units, possibly far away from home, which is a setting that could be particularly conducive to informal learning. Hence, recruits from poor backgrounds could benefit disproportionally from military service. In the context of the US armed forces, evidence suggests that recruits from disadvantaged groups benefit mildly from voluntary service in terms of earnings (Angrist, 1998). Using evidence from conscription during the Vietnam war, Angrist and Chen (2011) find no effects of military service on earnings but positive effects on education, which they attribute to schooling benefits provided under the GI bill. However, very little evidence

\footnotetext{
${ }^{1}$ During the colonial period, Punjab province had a total population of approximately 20 million individuals, comprising the present-day Punjab states in Pakistan and India, as well as the Indian states of Himachal Pradesh and Haryana.

${ }^{2}$ Khalidi (2001), and Moskos and Butler (1996).
} 
is available on how these findings translate to a developing country context. Nevertheless, the returns to military service in professional armies could be much higher in developing countries, as the average human capital in their populations tends to be lower. ${ }^{3}$ While the historical context of this paper is extraordinary in many ways, it is one of the first contributions to focus on voluntary and professional military service in a context of severe human capital underdevelopment.

Focusing on war-time recruitment in colonial Punjab allows this paper to address two important challenges in this literature. First, the confidentiality of military data restricts sub-national work. Second, selection into voluntary military service is typically non-random, which could bias the estimated returns to military service. The setting of colonial Punjab is unique in that recruitment patterns can be reconstructed. Also, exogenous factors determined the extent to which communities were exposed to a demand shock for military labor.

The recruitment patterns of the Indian Army during WWI can be proxied by the distribution of war casualties. The historical context supports the use of these casualty numbers as proxies for army recruitment: the Indian Army sent representative units on foreign missions in order to minimize the risk of mutiny. This paper will use information on war casualties from the "Debt of Honour Register" by the Commonwealth War Graves Commission. ${ }^{4}$ Individual records of Indian WWI casualties are aggregated to construct recruitment proxies at the district-religion level, i.e. for Hindu-Sikh and Muslim communities in each Punjabi district. Census data allow me to construct a panel of literacy outcomes at the district-religion level in colonial Punjab for the period 1901-31.

The identification strategy used in this paper corresponds to a continuous difference-indifference approach: I compare male literacy rates in years before and after WWI, between communities with different ratios of military war casualties. This approach relies on the fact that recruitment into the Indian Army was restricted to certain groups from specific geo-

\footnotetext{
${ }^{3}$ Stroup and Heckelman (2001) find a positive relationship between military spending and growth in countries with low levels human capital.

${ }^{4}$ The CWGC refers to deaths as "casualties", and I will use the same terminology in here.
} 
graphical areas. Recruitment patterns during WWI were based on the recruitment grounds that had been identified at the end of the 19th century. British recruitment officers relied on racist theories and pseudo-science to select recruitment grounds (Bingley, 1897, 1899). Their criteria had no obvious link to the potential for literacy improvements during WWI. Hence, the War exposed a predetermined set of communities to an enormous demand shock for military labor. Two important tests offer support for the exogeneity assumption. First, an analysis of the baseline characteristics shows that recruited communities did not enjoy significantly different pre-war literacy rates. Second, a placebo test in which the impact of war casualties is estimated before the start of the war confirms that war casualties cannot account for different literacy trends before the war.

The main result of this paper is that an increase in war casualties is associated with a significant increase in the number of male literates at the district-religion level. On average, ten additional recruits per thousand of the 1911 male population are associated with an increase in the male literacy rate by 2.4 per cent (proportional). At the sample mean (11\%), this corresponds to an additional 2.6 literates per thousand in 1931.

A range of robustness checks allows me to rule out alternative explanations of the main result. One concern is that increases in the literacy rate might be driven by a purely demographic effect, for example when the total population falls and the number of literates remain constant. However, the human capital gains hold for the number of literates as well. One could also be worried about recruitment based on determinants of literacy gains. I argue against such explanations by controlling for potential omitted variables (including districtlevel health outcomes, education measures, and agricultural land revenues at baseline). I also present IV results for a restricted sample, in which I can instrument the observed recruitment patterns with an indicator of "recruitment suitability" (based on the assessments by British recruitment officers at the end of the 19th century).

To shed further light on the mechanism explaining these literacy gains, I can compare different age groups. The positive impact on literacy immediately after the war (in 1921) 
turns out to be strongest for the group of men aged over 20. For the age-group of under20-year-olds, the effects of recruitment are imprecisely estimated, although the magnitudes are consistent with some (delayed) intergenerational spill-overs in 1931. These findings are consistent with the hypothesis that direct skill acquisition through informal learning was a key channel through which military recruitment influenced literacy. The magnitude of the estimated effect in 1921 is consistent with the hypothesis that these immediate literacy gains were limited to veterans. Historical work concurs that illiterate Indian Army recruits often picked up literacy skills through informal learning (Mazumder, 2003). Most importantly, literacy skills offered soldiers the opportunity to communicate with family members. A large number of secondary results confirm this informal learning channel. However, there is no evidence of increased educational investment in recruitment grounds by the Punjabi District Boards. Also, the positive impact does not extend to women. Finally, the effect is limited to the vernacular languages, which is consistent with the organization of the Indian Army along language lines.

Historians have long argued that serving in the Indian Army was a life-changing experience in many ways (Mazumder, 2003; Lawrence, 1997). Death, injury, illness, and psychological trauma were undoubtedly an important part of this experience. The human capital effects of military service are multidimensional: war trauma, for example, might be expected make entering the civilian labor force harder for recruits. This paper cannot provide a full cost-benefit analysis that taking all these impacts into account. Nevertheless, it is among the first papers to confirm the long-standing hypothesis that military service can boost certain human capital indicators in a context of severe underinvestment in education.

The remainder of this paper is organized as follows. First, I discuss the related literature. Second, I describe the historical context and I discuss the mechanisms through which military service could promote literacy. Third, I introduce the data set. Fourth, I present the empirical strategy. Fifth, I interpret the results. Then, I discuss the robustness of my findings. Finally, I offer concluding remarks. 


\section{Literature}

This paper adds to three main strands of work. First, this paper contributes to previous work on the economic impacts of military recruitment. This body of work has generally found small or negative economic impacts of conscription or of voluntary military service. ${ }^{5}$ However, my paper is one of the first contributions to provide evidence on the relationship between military recruitment and human capital formation in the context of a developing economy and a professional army. Annan and Blattman (2010) examine the labor market impact of forced child soldiering in Uganda. They conclude that military service is a poor substitute for schooling. ${ }^{6}$ However, it is not obvious that these results would carry through to the volunteer forces of professional armies. In a context that is closer to the one I study (the American Civil War), Costa and Kahn (2008) argue that black Union soldiers who served in more diverse companies experienced improved writing ability. ${ }^{7}$. Jha and Wilkinson (2012) share my focus on human capital accumulation in the Indian Army. Their analysis indicates that the combat experience of Indian WWII veterans helped these ex-soldiers to organize violence during the 1947 Partition. $^{8}$ My paper complements their study and suggests that the impact of military service could also have more benign aspects: improving the literacy skills of recruits and their families.

\footnotetext{
${ }^{5}$ Contributions on the individual returns to military service include Angrist (1990 and 1998) Angrist and Chen (2011), Angrist and Krueger (1994), Bedard and Deschenes (2006), Berger and Hirsch (1983), Imbens and van der Klaauw (2005), Grenet, Hart and Roberts (2011). Angrist and Chen (2011), Bound and Turner (2002), and Card and Lemieux (2001) study the effects of the US draft on educational outcomes. Based on cross-country evidence, Benoit (1978) argues that defense expenditures could spur growth in developing countries. Dunne, Smith and Willenbockel (2006) survey the more recent macro literature on military expenditures and growth. Stroup and Heckelman (2001) find a positive relationship between military spending and growth in countries with low levels human capital.

${ }^{6}$ These findings are consistent with survey evidence from the Sierra Leonean civil war (Humphrey and Weinstein, 2007). Blattman and Miguel (2010) review the literature on the role of veterans in post-war reconstruction and on the economic impact of civil war. Costa and Kahn (2010) find that US civil war veterans faced higher mortality due to war time stress. They also analyze the patterns of desertion (Costa and Kahn, 2003), and group loyalty (2007).

${ }^{7}$ While these results are consistent with the findings of my paper, these authors do not focus on the effect of military service. They identify the impact of company diversity. Lee (2012) finds that unskilled Union veterans in the Civil War experienced positive occupational mobility in comparison to unskilled nonveterans. However, this approach presents a range of endogeneity concerns. The context of colonial Punjab is appealing, because it lends itself to a D-i-D approach that overcomes several identification challenges.

${ }^{8}$ Focusing on political attitudes, Grossman et al. (2013) find that combat experience in the Israeli Army tended to promote the support of hard-line approaches in the Israeli-Palestinian conflict.
} 
Second, this paper relates to the large literature on literacy and education. While public education reaches an ever growing number of students in the developing world, educational attainment remains low. ${ }^{9}$ In the context of the Indian Army, military service could have boosted literacy by increasing the personal returns to acquiring these skills. While the experience of the Indian Colonial Army during WWI was extraordinary, these results are consistent with recent work that highlights how non-traditional and informal learning environments can improve educational outcomes, in particular for adult learners (Aker et al., 2011)..$^{10}$

Finally, this paper contributes to the fast growing body of research on the economic effects of colonial institutions. In their critique of Acemoglu et al. (2001), Glaeser et al. (2004) emphasize that colonizers exported human capital alongside institutions. These authors point out that there is very little evidence on which specific colonial policies promoted institutional development or human capital accumulation. Bridging this gap in our understanding of colonial economic history, a large literature has recently emerged on the economic impact of specific colonial institutions. ${ }^{11}$ Chaudhary $(2009 ; 2010)$ shares my focus on human capital accumulation in colonial India. She finds that public spending on primary education is positively associated with male literacy. This paper complements her findings by exploring if military service could promote human capital development in this context of severe underinvestment in education. The promotion of literacy skills in the context of the Indian Army also bears resemblance to interactions in India's industrial sector. In this context, Clingingsmith (2014) argues that the industralization wave of the first half of the 20th century promoted bilingualism in India. More broadly, it is striking that, in the large literature on colonial institutions, the role of colonial armies has received little attention. ${ }^{12}$ Nevertheless,

\footnotetext{
${ }^{9}$ UNESCO (2008). See also Glewwe and Kremer (2006), and Duflo, Dupas and Kremer (2009).

${ }^{10}$ These authors evaluate a program that teaches adults to read and write by using mobile phones.

${ }^{11}$ See for example Acemoglu, Johnson and Robinson (2001), Banerjee and Iyer (2003), Cassan (2009), Cogneau (2008), Dell (2010), Donaldson (2009), Huillery (2009), and Moradi (2008).

${ }^{12}$ Moradi $(2008,2009)$ uses information on recruits in the African colonial armies to assess the impact of colonization on nutritional status, but he does not assess the developmental impact of military recruitment in itself. Fafchamps and Moradi (2010) find that soldiers entering the British Army in Ghana based on referrals performed worse than non-referred colleagues. Echenberg (1975) argues that conscription in French
} 
one could argue that no other colonial institution required as much close collaboration and interdependency between local non-elite groups and their colonizers. This paper is one of the first to offer insights on the developmental effects of colonial army service.

\section{Context and Conceptual Framework}

\subsection{Context of military recruitment in WWI India}

The Indian Army entered the war in 1914 (Mason, 1974, p. 410). Raw figures illustrate the enormous scale of the war-time recruitment effort in colonial India: out of a population of approximately 20 million, the number of Punjabi troops increased from 69,458 to 362,027 over the period 1910-19 (1.8\% of the population). During the war, India sent 138,000 men to France, 675,000 men to Mesopotamia, and 144,000 men to Egypt. Of these 957,000 recruits, at least 74,260 men died, of whom approximately 19,000 had been recruited in Punjab. ${ }^{13}$ The Indian army kept on playing an important role in the Middle East and on the Indian-Afghan border until 1921 (i.e., after Armistice). Therefore, full demobilization of WWI recruits was not reached until the mid 1920s.

\subsection{Recruitment practices}

\subsubsection{History of recruitment}

While the Indian Army relied solely on volunteers, its recruitment practices were guided by severe constraints on which groups and which regions were deemed fit for recruitment. The recruitment patterns of the Indian Army were remarkably persistent, and recruitment policies in place during the First World War had been established in the second half of the 19th century. The 1857 Sepoy mutiny had justified a shift in the recruitment patterns away from high-caste Hindus from present-day UP, who had constituted the core of the pre-mutiny

West Africa during the WWI contributed to its economic stagnation.

${ }^{13}$ Figures drawn from Mazumder (2003, p.18) and the CWGC Debt of Honour Register. 
army. The supposedly superior fighting skills of the "martial races", who were predominantly living in North-West India, were deemed to be crucial for the Indian Army to withstand a Russian invasion of India. Recruitment handbooks, commissioned by the QuartermasterGeneral, provided religion-specific assessments of the 'martialness' of the population at the district or even village level. ${ }^{14}$ This approach led to stark differences in recruitment at the district-religion level, consistent with British demand side constraints being the most important source of variation. Recruitment practices in the late 19th century onwards helped to entrench the existing composition of the army. Firstly, the army relied on the networks of serving soldiers to identify good recruits in their home villages through so-called "direct enlistments". Secondly, the alternative recruitment channel, so-called "class recruitment" meant that existing regiments sent out recruitment parties to particular villages (Leigh, 1922, p.33). The efforts of the recruitment parties would be focused on those villages that had been identified as fruitful recruitment grounds in the handbooks (Sikhs, Dogra Hindus, Jat Hindus, and Muslims). The result of these recruitment policies was that recruitment patterns did not change substantially during the First World War, although some efforts were made towards the end of the war to broaden recruitment (Cohen, 1971, and Leigh, 1922). Still, the main effect of increased military recruitment during WWI was an enormous demand shock for military labor in those groups that had already been identified as suitable military recruitment grounds (Cohen, 1971, p.69; Leigh, 1922, p.33), and the data used in this paper will support predetermined recruitment patterns (see section 5.2.1).

\subsubsection{Selection criteria}

The selection criteria used in the recruitment handbooks were multiple. Recruitment efforts were entirely focused on rural peasants (Mazumder, 2003, p. 93). As $90 \%$ of the Punjabi population was rural (Census Report 1911) and 60\% listed agriculture as its main occupation, this preference did not constrain recruitment. At the group level, "good physique" was a clear priority and was preferably obtained through agricultural labor, groups had to be obedient,

\footnotetext{
${ }^{14}$ Falcon (1892), Bingley (1897;1899), Bourne (1914) and Wikeley (1915).
} 
they had to take "pride" in their caste, and they needed to refrain from "thieving" and "quarreling" and be free from "intrigues" (Bingley, 1897; Bingley, 1899; Bourne 1914; and Wikeley 1915). In general, communities with a richer war history were also favored, possibly because this was one of the few sources of objective information the recruitment handbooks could refer to. Importantly, intellectual ability and literacy status were not among the selection criteria. $^{15}$ For example, praising the fighting skills of Jat Sikhs, Falcon writes (1892, p.107):

"Hardy, brave and of intelligence too slow to understand when he is beaten, obedient to discipline, devotedly attached to his officers [...], he is unsurpassed as a soldier in the East [...]"

While recruitment was organized per religion (or the smaller "classes"), regional characteristics were deemed to be very important:

"From a recruiting perspective, Jats vary considerably according to the locality in which they are found. While in one district they are worthless as soldiers, in another district they are well worthy of consideration" (Wikeley,1915, p.5)

Many of the regional characteristics of potential recruits that were deemed relevant appear to be based on anecdotal insights or pseudo-anthropology:

"The cultivation of sugar cane to any great extent seems to me to give a softer character to the cultivator" (Falcon, 1892, p.83)

It is striking that certain recruitment criteria are apparent contradictions. For example, harder agricultural conditions are thought to make farmers less lazy, but their physique could suffer at the same time (Bingley, 1987, p.68). Taking pride in caste is sometimes seen as a positive characteristic (Bingley, 1899, p.67), but in the context of Jat Sikhs, Bingley (1899, p.82) mentions that less rigorous caste restrictions make them more suitable for service.

\footnotetext{
${ }^{15}$ Mazumder (2003, p.38): "Recruits were enlisted when they were in their mid-teens and had little knowledge of anything outside restricted village life. More often than not, they were illiterate".
} 
Similarly, a history of war is often deemed to be positive, but certain tribes are dismissed for being "quarrelsome" (Bourne, 1914, p.90). Leigh (1922) explicitly writes that the recruitment patterns lacked objectivity:

"There was also considerable exclusiveness on the part of the army; certain tribes capable of providing excellent material were barred by reason of some real of fancied social objection. [...] Some quite respectable agricultural tribes were ignored, because their tribe-name was unfamiliar and therefore suspect." (Leigh, 1922, p.33)

It is important to keep in mind that selection at the community level and at the individual level were different. Individual candidates from classes and regions that were deemed fit for recruitment still had to meet certain physical standards. ${ }^{16}$ However, eligibility at the higher level (per class and region) was a necessary condition: recruitment parties went through thorough verification of the caste and origin of recruits (and were personally held responsible if the origin turned out to be wrong), to prevent candidates from misrepresenting their recruitment class (Wikeley, 1915, p.126). Because of the reliance of the Indian Army on religion-specific recruitment grounds, it is natural to estimate the aggregate returns to military service at the level of religious communities in each district.

\subsection{Mechanisms}

Average male literacy was only around $7 \%$ in colonial Punjab, and it was even lower in agricultural villages (Bourne, 1914, p.25). Given the recruitment practices of the Indian Army, it is unsurprising that most recruits were illiterate (Mazumder, 2003, p.38; Corrigan, 1999, p.11; Bingley, 1897, p.71; Bingley,1899,p.91). In such a context of severe human capital deficiency, we might expect the impact of professional military service to be most pronounced. A priori, there are multiple channels through which military recruitment could

\footnotetext{
${ }^{16} \mathrm{~A}$ minimum chest and height measures, no varicose veins, no lock-knees, and bad flat feet (Wikeley, 1915, p.127)
} 
affect literacy outcomes at the district-religion level. Three of these mechanisms have been highlighted by the historical literature: (i) direct skill acquisition by serving soldiers, (ii) increased demand for education due to higher earnings, or (iii) preferential public spending on primary education.

First, soldiers could acquire literacy skills on service. Formal literacy courses were not part of the training that the large numbers of new WWI recruits received. However, historical accounts highlight the strength of the personal relationships between British officers (who would typically be able to speak and write in the local language of the regiment), Indian junior officers and the soldiers under their command. They point out that skills were often transferred informally during the many hours that soldiers had "to kill" in their small companies. ${ }^{17}$ Such a direct learning channel appears to be referred to by the census report of 1931:

"[...] Ludhiana and Shahpur, and most of the districts with the next highest percentage of increase [...], also owe the increase in literacy to the return home of demobilized soldiers, who very often pick up reading and writing in Roman or any other of the vernaculars in the course of their military career." (Khan, 1932, p216)

Similar statements can be found in the reports of the Censor of letters from soldiers serving abroad (Censor of Indian Mail, 1915):

"Under stress of necessity many Indian soldiers during their stay in Europe have learned to read and write their own languages, and primers and spelling books come in large quantities from India to the army."

The latter quote suggests that the main channel through which soldiers acquired literacy was not formal training, but the boost in the returns to becoming literate. In other sections,

\footnotetext{
${ }^{17}$ Mazumder (2003). Costa and Kahn (2008) argue that the positive effect of company diversity on the writing ability of black veterans reflects a similar informal learning mechanism in the Union Army during the American Civil War.
} 
the Censor Reports mention several contributing factors. First, the Indian Army maintained a postal service. Hence, literacy skills facilitated the communication between soldiers and their families substantially and this could be an important incentive to learn how to read and write. Interestingly, the communication channel could create spill-overs to the home community. Given that my study identifies an impact on aggregate literacy, I cannot distinguish between the impact on serving soldiers and the spill-overs to their families who remained in India. ${ }^{18}$ The Censor of Indian Mail (1915) also gives many examples of letters between soldiers to share information about the course of the war. ${ }^{19}$ An additional incentive to acquire literacy skills was the uneventful nature of military life outside of the battlefield and the strong demand for leisure activities. In response to this demand, the Indian Army brought soldiers news from India and from the front line. Similarly, charity organizations provided soldiers with a steady supply of religious literature (Corrigan, 1999, p.201). Finally, the prospect of promotion to Non-Commissioned Officer roles was important as a general motivation for soldiers (Corrigan, 1999, p.19, p.21). These aspirations could have served as an additional incentive to gain literacy skills, although it is not clear from the consulted sources whether literacy was a requirement for all ranks above the soldier level. Rather than formal promotion, literacy skills may also have enabled soldiers to become readers and writers for their peers, which might have lifted their status or delivered material benefits. In brief, the military could provide a unique environment, in which the costs of acquiring literacy skills were reduced and the returns to those skills were boosted.

A second channel through which military recruitment could affect literacy is through an income effect. The inflow of military income could have fuelled a demand shock for education.

\footnotetext{
${ }^{18}$ In the following letter, a Punjabi soldier emphasizes his own (newly acquired) literacy. He writes about the difficulty of communication and the encouragement from the Army: "You write, saying that my letters cannot be read. I write them myself with my own hand. Some of them may be written in a hurry, and then you people may have to get them read to you. But I generally write in a fair round hand. Today I got an envelope in which there were sixteen blank envelopes and sixteen sheets of writing paper. My brother, we get plenty of paper and envelopes here" (Censor of Indian Mail, 1915)

${ }^{19}$ A Garhwali soldier writes: "You wrote that regiments have gone away to the Dardanelees? You have no idea I suppose what will become of our regiment. Those faithless ones who run the Hindi newspapers, have said that food soldiers among the Indian regiments have gone back to India and the Cavalry regiments will stay in France." (Censor of Indian Mail, 1915)
} 
The recruited communities were most likely to be affected by the remittances of soldiers and by pensions for ex-soldiers. Mazumder (2003) provides descriptive evidence of the impact of military incomes on a large number of outcome variables, including clothing, housing, dietary choices and education. Mazumder notes that "(t)he education of children was another investment soldiers willingly made" (2003, p.42). The income effect could have been boosted further by preference changes that were induced by military service. While demand for education (as a normal good) should increase in response to an inflow of income, the loss of male labor forces in the home communities due to the mobilization of men for military service can counteract this effect. In the presence of credit and labor market imperfections, the opportunity cost of sending children to school may increase substantially if households have less labor available to work on their land. Hence, the opportunity cost effect could outweigh the income effect and the impact of large-scale military recruitment on the demand for education remains theoretically ambiguous.

A third channel through which military recruitment may influence literacy is the supply of education. It is possible that heavily recruited communities attracted more public spending on education. The success of the military in securing favors for its personnel is indeed a central theme in the political economy literature on the military (Collier and Hoeffler, 2007). However, the Government of India faced an important trade-off from a recruitment perspective if it was to invest in educating its recruitment grounds: promoting schooling might raise the reservation wage of future recruits (Pasha, 1998). Moreover, the Indian Army could only exert indirect influence over education spending. The responsibility for investments in primary education lay with the District Boards. Chaudhary (2010) reports that the District Boards accounted for $18 \%$ of total spending on education, $85 \%$ of total primary education spending and 93\% of public spending on education in Punjab in 19121913. Her evidence suggests that revenues from land taxes were the main determinant of public spending on education. Hence, increasing public spending on education could come at the cost of higher taxation. Nevertheless, it remains possible that the Indian Army could 
push the district boards to invest more in education in the recruitment grounds, both as an indirect remuneration of its soldiers in response to their political pressure and as an attempt to boost the skills of its future recruits. An important caveat is that supply and demand factors could interact in reality: lack of public investment in education might suppress an income effect.

As is clear from this section, the (relative) importance of these channels is not clear. In an attempt to distinguish between these mechanisms, the empirical analysis relies on four approaches. First, I repeat the main analysis for different age groups. If demobilized soldiers are driving the results, the effects should be strongest for men of military age and they should be visible immediately after the war. Second, I analyze investment data on education. Assuming that these reflect the independent decisions of the local authorities of how much to fund education in a given district, higher investment in recruited districts could reflect a supply shock. If investment does not change, then a demand-driven change is more likely. Finally, I report impacts of recruitment on female literacy. If female literacy benefits from military recruitment, this suggests spill-overs are important.

\section{Data}

In my main analysis, I use military war casualties as proxies for military recruitment. I collect data on the district of origin from a list of soldiers who died during WWI, the "Debt of Honour Register". This register is administered by the Common Wealth War Graves Commission (CWGC) and has the names of 74,260 Indian military personnel who died in WWI. For virtually all soldiers, the name, the rank, the regiment and the date of death are provided. For $68 \%$ of entries, the name of the father and the district of birth have been 
recorded. ${ }^{20}$ I was able to match 19,074 individuals to a district in Punjab. ${ }^{21}$ Based on the information in the register, I also use the names of soldiers to assign them to two religious groups: Hindu-Sikh or Muslim. ${ }^{22}$ These individual records are subsequently aggregated at the district-religion level for the main analysis, as this is the lowest level at which I can measure literacy outcomes in the census. To mitigate concerns regarding selective mortality, I use the 17,006 Punjabi deaths among the purely military regiments. ${ }^{23}$

The use of war casualties as a proxy for recruitment patterns raises concerns about selective mortality, but direct recruitment estimates at the district level do exist. Leigh (1922, p.61-62) estimated district-level recruitment based on local sources (the District War Histories) shortly after the war. Figure 1 shows the correlation between Leigh's recruitment estimates and the casualty-based proxy at the district level. The recruitment patterns are very similar, and the correlation coefficient is $0.94 .{ }^{24}$ While Leigh's measure has the advantage of being directly based on recruitment, it has considerable drawbacks as well. First, it does not split up recruitment by religion, whereas the geographical recruitment patterns were highly religion specific and literacy outcomes can be measured per religious group. Second,

\footnotetext{
${ }^{20}$ This information should have been recorded on the individual service records of all soldiers. According to CWGC, the missing information is most likely due to poor performance on the part of clerks who recorded the information of new recruits. These differences in the punctuality of individual recruitment clerks are unlikely to produce systematic errors. The loss of service records and the ease with which they could be accessed by the Indian administrators who prepared the information for the CWGC is another potential cause of missing records. These hypotheses were put forward by Peter Holton, Records Supervisor at the CWGC.

${ }^{21}$ I focus on Punjab for three main reasons. First, the identification strategy will rely on the fact that recruitment patterns were pre-determined and based on the martial races theory, which was specific to Punjab. Second, Punjab experienced a combination of very lightly and very heavily recruited districts. The latter were so important that it is plausible that literacy effects can be observed at the level of aggregate census outcomes. Other Indian states saw less concentrated recruitment, and it is a priori unclear whether the empirical strategy would work. Third, by focusing on one state, the analysis implicitly holds a wide range of unobserved policy variables constant. As a result, the analysis is more likely to uncover the causal mechanism.

${ }^{22}$ The algorithm relies on the recognition of Muslim names (such as "Khan" and "Abdullah") or Hindu-Sikh Names (such as "Singh" and "Ram") in either the name of the father or the name of the casualty. Certain names (in particular "Singh") that are common to Hindus and Sikhs prevent a further split-up.

${ }^{23}$ The Indian army did not just employ soldiers, but hired personnel in a multitude of roles. Approximately $10 \%$ of the Punjab casualties were employed as laborers or as part of the transport corps. My estimates only include purely military regiments, as the recruitment practices in non-combatant regiments may not have followed the same principles as the recruitment principles for combatants.

${ }^{24}$ Jha and Wilkinson (2012) can compare recruitment estimates from the CWGC casualty records to actual recruitment numbers for certain provinces, including Punjab, during the Second World War. They also find that casualty data are "broadly reflective" of recruitment patterns.
} 
Leigh's recruitment numbers do not distinguish between combatant and non-combatant roles, whereas the martial races theory applies to soldier roles only. Third, Leigh's estimates of the "number of males of military age" suggest that temporary residents or seasonal workers were not counted in their home districts, in contrast to the casualty data. ${ }^{25}$ Fourth, Leigh himself admits that "[his numbers] cannot claim to be quite exact", because of double-counting and failure to correct for recruits who were quickly found to be unsuitable (Leigh, 1922, p.33). In spite of these caveats, the strong correlation between direct recruitment estimates and the casualty proxies suggests that the risk of death was proportional to recruitment. In the paper, I will use the casualty based proxy for the main results at the district-religion level (and section 5 discusses remaining endogeneity concerns), but all district level results are robust to using Leigh's recruitment statistics (e.g. Table 5).

\section{Figure 1: Recruitment and casualty shares at the district level}

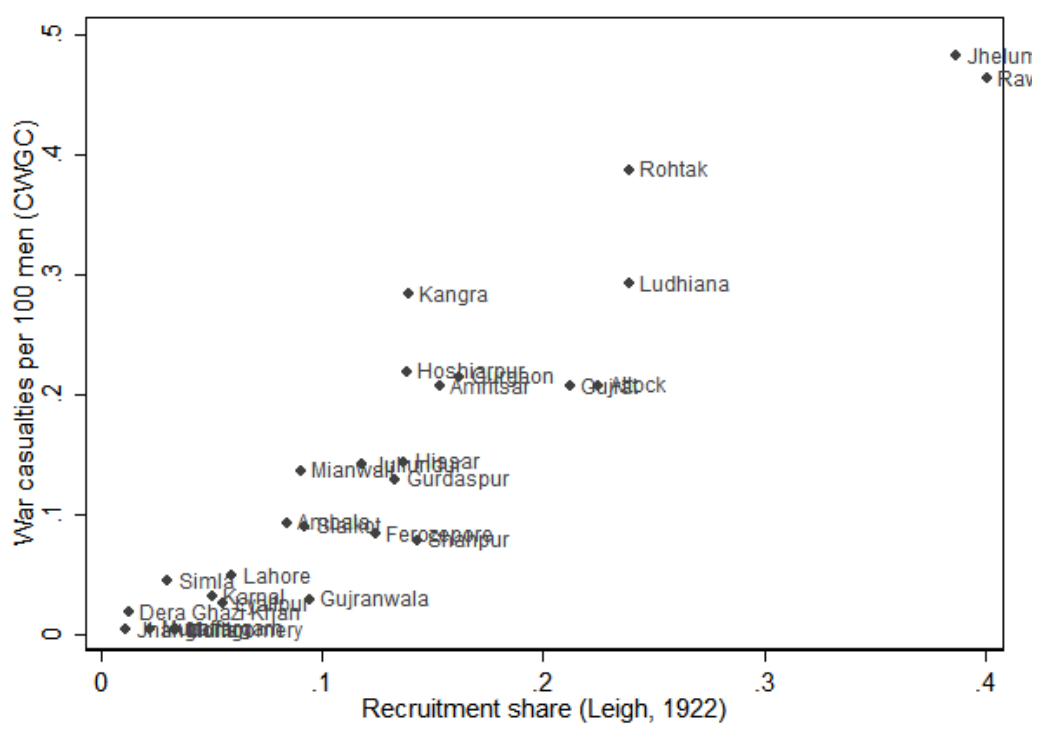

Notes: Observations are for 28 districts. Casualty shares are expressed per 100 of the 1911 male population, and recruitment shares as a fraction of the eligible male population according to Leigh (1922).

Literacy and population details for each of the three religious groups are collected at the district level in Punjab for the four census years (1901, 1911, 1921 and 1931). Twenty-eight districts provide literacy data for the three most recent census years. Nominal expenditures

\footnotetext{
${ }^{25}$ Simla is reported as having 72,500 men of military age by Leigh, but its 1911 male census population is only 24,718 . As the summer capital of British India, Leigh's numbers need to include temporary workers.
} 
on education by the District Boards are also collected for each of the census years at the district level. ${ }^{26}$ While the census data are very rich, they still give rise to certain measurement concerns. First, the definition of literacy changed over the sample period. In the 1901 census, literates were expected to be able to "both read and write" in any language (Kaul, 1912, p316). In practice, it was often sufficient for respondents to be able to spell out words from a book or to be able to sign with one's name to be recorded as "literate" (Kaul, 1912). From 1911 onwards, the definition became stricter: "(a) person should not be entered as literate unless he can write a letter to a friend and read the answer to it". While this change in definition makes the literacy numbers not directly comparable, the inclusion of year-effects in my econometric specification can account for the effect of this administrative change that was common to all units of observation. While differences in enumerator practices are unlikely to give rise to systematic measurement error, I choose not to include 1901 in the sample for the main results (although I use the 1901 data to estimate pre-treatment effects). ${ }^{27} \mathrm{~A}$ second measurement concern relates to the border changes that several districts underwent over the sample period. The appendix (A.3.1) presents results for merged districts that are very similar.

Table 1 presents summary statistics for all the key variables at the district-religion level, and figure 4 (in the online appendix) maps the number of war deaths as a proportion of the 1911 population). The maps show clearly that recruitment patterns were highly religion specific within each district, which supports my analysis at the district-religion level. As my analysis relies on the comparison of communities that were recruited with varying intensity, I provide separate summary statistics for 'heavily' and 'lightly recruited' districts (based on whether the ratio of war casualties is above the sample mean). The share of casualties in the

\footnotetext{
26"Reports on the Progress of Education in the Punjab", annual from 1892-1931. District-level mortality data in 1911 and post volume data between 1906 and 1923 (observed intermittently for 5 year periods) were collected from the District Gazetteers. District-level land revenues are drawn from the Report on the Land Revenue Administration of the Punjab 1911-1912.

${ }^{27}$ Chaudhary (2010) does not include 1901 in her sample on the grounds that the 1901 data on literacy would suffer from substantial variation across provinces in the methods adopted. As I focus on just one province, the 1901 data should be comparable in the cross-section and any definition changes that have proportional effects within the province do not bias my results.
} 
1911 population is approximately one per thousand at the sample mean. While recruited communities tend to be less literate on average, this difference is not significant. However, the increase in the male literacy rate (1911-31) is significantly higher for the heavily recruited communities. $^{28}$ This is the first piece of evidence in favor of the hypothesis that military service promoted literacy. The main results will exclude the Princely States, which were not directly ruled by the British authorities. Colonial publications often did not provide data for these areas. Moreover, military recruitment may have followed a different logic in the Princely States. ${ }^{29}$

In Table 2, summary statistics are provided at the district level. Most of the differences in baseline variables fail to gain significance. One exception is the colony status of districts. These districts were recipients of extensive irrigation projects. The newly available agriculture land in these districts explains why they tended to have a larger share of the population born outside of district of enumeration. The potentially confounding effect of colony status and migration is dealt with explicitly in the robustness checks: the relevant coefficients remain significant in specifications in which this baseline difference is controlled for (Table $6)$.

\footnotetext{
${ }^{28}$ I focus on the male population because this group is most directly affected by military recruitment and educational policies. Female literacy in Punjab was only around 1\% on average in 1911. Section 7 discusses female literacy in more detail.

${ }^{29}$ Corrigan (1999, p.23). Including the princely states could give rise to comparability concerns (Iyer, 2006). One dimension in which princely states differed from British districts is their size. Certain religious communities in Princely states had an extremely low population sizes. The smallest Princely State communities (with a 1911 male population of less than 2,000 individuals) are influential outliers. Because of their small size, they experienced very large proportional changes in their literacy outcomes.
} 


\section{Table 1: Summary statistics (district-religion level)}

\begin{tabular}{|c|c|c|c|c|}
\hline & $\begin{array}{c}\text { Sample } \\
\text { (1) }\end{array}$ & $\begin{array}{l}\text { Lightly } \\
\text { recruited } \\
(2)\end{array}$ & $\begin{array}{c}\text { Heavily } \\
\text { recruited } \\
(3)\end{array}$ & $\mathrm{P}$-value (2)-(3 \\
\hline Male literacy rate 1911 & $\begin{array}{c}0.11 \\
(0.12)\end{array}$ & $\begin{array}{c}0.12 \\
(0.13)\end{array}$ & $\begin{array}{c}0.10 \\
(0.11)\end{array}$ & 0.57 \\
\hline Male population 1911 & $\begin{array}{c}187,428 \\
(111,440)\end{array}$ & $\begin{array}{c}176,058 \\
(114,369)\end{array}$ & $\begin{array}{c}207,893 \\
(105,678)\end{array}$ & 0.30 \\
\hline Muslim dummy & $\begin{array}{c}0.50 \\
(0.50)\end{array}$ & $\begin{array}{c}0.58 \\
(0.50)\end{array}$ & $\begin{array}{c}0.35 \\
(0.49)\end{array}$ & $0.10^{*}$ \\
\hline $\begin{array}{l}\text { Difference in literacy rate } \\
(1921-1911)\end{array}$ & $\begin{array}{l}-0.003 \\
(0.004)\end{array}$ & $\begin{array}{l}-0.008 \\
(0.039)\end{array}$ & $\begin{array}{c}0.005 \\
(0.015)\end{array}$ & $0.07^{*}$ \\
\hline $\begin{array}{l}\text { Difference in literacy rate } \\
(1931-1911)\end{array}$ & $\begin{array}{c}0.019 \\
(0.036)\end{array}$ & $\begin{array}{c}0.012 \\
(0.038)\end{array}$ & $\begin{array}{c}0.031 \\
(0.031)\end{array}$ & $0.05^{*}$ \\
\hline $\begin{array}{l}\text { Casualty rate } \\
\text { (per } 100 \text { of the } 1911 \text { male } \\
\text { population) }\end{array}$ & $\begin{array}{l}0.13 \\
(0.15)\end{array}$ & $\begin{array}{l}0.04 \\
(0.04)\end{array}$ & $\begin{array}{r}0.30 \\
(0.13)\end{array}$ & $<0.01^{* * *}$ \\
\hline Observations & 56 & 36 & 20 & \\
\hline \multicolumn{5}{|c|}{$\begin{array}{l}\text { Notes: District-religion level observations for } 56 \text { groups (Muslim or Hindu-Sikh, in } 28 \\
\text { districts). Heavily recruited communities have casualties above the sample average ( } 0.13 \\
\text { deaths per 100). The table records sample averages and standard deviations (in parentheses). } \\
\text { P-values are for a t-test of the equality of means. }{ }^{* * *} \mathrm{p}<0.01,{ }^{* *} \mathrm{p}<0.05,{ }^{*} \mathrm{p}<0.1 \text {. }\end{array}$} \\
\hline
\end{tabular}


Table 2: Summary statistics (district level)

\begin{tabular}{|c|c|c|c|c|}
\hline British Districts & $\begin{array}{c}\text { Sample } \\
(1)\end{array}$ & $\begin{array}{l}\text { Lightly } \\
\text { recruited } \\
\quad(2)\end{array}$ & $\begin{array}{l}\text { Heavily } \\
\text { recruited } \\
\quad(3)\end{array}$ & $\begin{array}{c}\text { P-value } \\
(3)-(2)\end{array}$ \\
\hline $\begin{array}{l}\text { Casualty rate (per } 100 \text { men in } \\
\text { 1911) }\end{array}$ & $\begin{array}{c}0.15 \\
(0.14)\end{array}$ & $\begin{array}{r}0.06 \\
(0.05)\end{array}$ & $\begin{array}{r}0.30 \\
(0.11)\end{array}$ & $<0.01^{* * *}$ \\
\hline $\begin{array}{l}\text { Recruitment rate (Leigh, 1922) } \\
\text { (in eligible male population) }\end{array}$ & $\begin{array}{c}0.13 \\
(0.10)\end{array}$ & $\begin{array}{c}0.07 \\
(0.05)\end{array}$ & $\begin{array}{c}0.23 \\
(0.10)\end{array}$ & $<0.01^{* * *}$ \\
\hline Male literacy rate 1911 & $\begin{array}{c}0.07 \\
(0.04)\end{array}$ & $\begin{array}{c}0.07 \\
(0.04)\end{array}$ & $\begin{array}{c}0.07 \\
(0.02)\end{array}$ & 0.76 \\
\hline Male population 1911 & $\begin{array}{c}379,601 \\
(125,758)\end{array}$ & $\begin{array}{c}392,421 \\
(142,958)\end{array}$ & $\begin{array}{l}356,524 \\
(89,001)\end{array}$ & 0.42 \\
\hline $\begin{array}{l}\text { Primary education spending } \\
1911\end{array}$ & 0.16 & 0.16 & 0.16 & 0.86 \\
\hline $\begin{array}{l}\text { (Rs per male population } \\
\text { under } 20 \text { ) }\end{array}$ & $(0.13)$ & $(0.03)$ & $(0.14)$ & \\
\hline $\begin{array}{l}\text { Primary school students } \\
\text { in } 1914 \text { (per male population } \\
\text { under } 20 \text { ) }\end{array}$ & $\begin{array}{l}0.05 \\
(0.02)\end{array}$ & $\begin{array}{l}0.04 \\
(0.02)\end{array}$ & $\begin{array}{l}0.05 \\
(0.01)\end{array}$ & 0.11 \\
\hline Colony dummy & $\begin{array}{c}0.25 \\
(0.44)\end{array}$ & $\begin{array}{c}0.38 \\
(0.50)\end{array}$ & $\begin{array}{c}0.00 \\
(0.00)\end{array}$ & $0.01^{* * *}$ \\
\hline $\begin{array}{l}\text { Fraction of males in } 1911 \text { born } \\
\text { in district of enumeration }\end{array}$ & $\begin{array}{c}0.87 \\
(0.15)\end{array}$ & $\begin{array}{c}0.83 \\
(0.18)\end{array}$ & $\begin{array}{c}0.93 \\
(0.04)\end{array}$ & $0.05^{* *}$ \\
\hline $\begin{array}{l}\text { Population density } \\
\text { (1911 male population/ha) }\end{array}$ & $\begin{array}{c}149 \\
(83.6)\end{array}$ & $\begin{array}{c}142 \\
(87.2)\end{array}$ & $\begin{array}{c}161 \\
(79.5)\end{array}$ & 0.56 \\
\hline $\begin{array}{l}\text { Fraction of Muslims } \\
\text { (in } 1911 \text { male population) }\end{array}$ & $\begin{array}{c}0.56 \\
(0.27)\end{array}$ & $\begin{array}{c}0.59 \\
(0.24)\end{array}$ & $\begin{array}{c}0.51 \\
(0.33)\end{array}$ & 0.50 \\
\hline $\begin{array}{l}\text { Fraction of Sikhs } \\
\text { (in } 1911 \text { male population) }\end{array}$ & $\begin{array}{c}0.10 \\
(0.10)\end{array}$ & $\begin{array}{c}0.09 \\
(0.08)\end{array}$ & $\begin{array}{c}0.11 \\
(0.14)\end{array}$ & 0.79 \\
\hline $\begin{array}{l}\text { Land revenues in } 1911 \\
\text { (Rs per male population) }\end{array}$ & $\begin{array}{c}2.8 \\
(0.9)\end{array}$ & $\begin{array}{c}2.8 \\
(0.9)\end{array}$ & $\begin{array}{c}2.9 \\
(0.7)\end{array}$ & 0.62 \\
\hline $\begin{array}{l}\text { Mortality rate } 1906-1910^{\dagger} \\
\text { (deaths per } 1,000)\end{array}$ & $\begin{array}{c}40.3 \\
(36.5)\end{array}$ & $\begin{array}{l}38.3 \\
(9.0)\end{array}$ & $\begin{array}{l}43.6 \\
(6.0)\end{array}$ & 0.12 \\
\hline Agricultural earners rate 1911 & $\begin{array}{c}0.36 \\
(0.06)\end{array}$ & $\begin{array}{c}0.35 \\
(0.05)\end{array}$ & $\begin{array}{c}0.37 \\
(0.07)\end{array}$ & 0.40 \\
\hline Observations & 28 & 18 & 10 & \\
\hline \multicolumn{5}{|c|}{$\begin{array}{l}\text { Notes: District level observations in } 28 \text { districts. Heavily recruited districts have casualty rates } \\
\text { above the sample average }(0.15) \text {. The table records sample averages and standard deviations } \\
\text { (in parentheses). }{ }^{\dagger} \text { This data was available for } 21 \text { districts, of which } 8 \text { are heavily recruited. } \\
\text { P-values are based on a t-test on the equality of means. }{ }^{* * *} \mathrm{p}<0.01,{ }^{* *} \mathrm{p}<0.05,{ }^{*} \mathrm{p}<0.1 \text {. }\end{array}$} \\
\hline
\end{tabular}




\section{$5 \quad$ Empirical strategy}

\subsection{Main specification}

To account explicitly for the possibility that the recruited communities enjoyed different time-invariant characteristics, the main identification strategy is based on the comparison of literacy rates in years before and after the war, for heavily and lightly recruited communities. This approach could be interpreted as a continuous difference-in-difference analysis. The corresponding econometric specification is:

$$
\log \left(\operatorname{lit}_{r, d, t}\right)=\sum_{\tau=1921,31} \beta_{\tau} *\left(\operatorname{cas}_{r, d, 1911}\right) * I(t=\tau)+\varphi_{r, t}+\theta_{r, d}+\varepsilon_{r, d, t}
$$

$\log \left(\operatorname{lit}_{r, d, t}\right)$ is the logarithm of the male literacy rate of religion $r$ in district $d$ in year $t$ (1911, 1921, 1931). $\beta_{1921}$ and $\beta_{1931}$ are the key parameters of interest. They measure the impact of the intensity of military recruitment, as proxied by the casualty rate, on subsequent literacy rates. $\varphi_{(r, d)}, \theta_{(r, t)}$ are respectively district-religion, and religion-year fixed effects. ${ }^{30}$

In $\log \left(\right.$ literacy $\left.y_{r, d, t}\right)$, the use of the literacy rate raises the concern that effects could be driven by the denominator (the total male population) instead of the numerator (the total number of literates). To account for this possibility, the main specification is repeated with the logarithm of the size of the male population as the dependent variable. One of the advantages of focusing on the logarithm of the literacy rate is the easy decomposition in effects on literates and the population size. The logarithmic specification also accounts for differences in the level of the dependent variable across communities, because it ensures the proportionality of all estimated effects. On theoretical grounds, one can expect the process that is driving the creation of more literates to be multiplicative to the existing stock of literates. ${ }^{31}$ The impact of military recruitment is captured by the coefficients $\beta_{\tau}$

\footnotetext{
${ }^{30} \mathrm{As}$ recruitment patterns are proxied at the district-religion level and casualty rates also vary at this level, a district-religion is the natural unit of observation in this context. In the main tables, I use standard errors adjusted for clusters at the district-religion level, but using district level clusters instead does not affect the significance of the main results (appendix A.3.2).

${ }^{31}$ The findings are robust to alternative functional specifications of the dependent variable, including the
} 
on the number of war deaths per 100 of the 1911 male population for a religious group $\operatorname{cas}_{r, d, 1911}$. The estimation of two separate coefficients allows me to interpret the timing of the effect. The religion-time fixed effects $\theta_{(r, t)}$ account for factors that affect the literacy of all communities of the same religion in Punjab. The inclusion of religion-year effects (rather than just year-effects) can be justified because Muslim communities were characterized by larger proportional increases in literacy rates than Hindu-Sikh communities during the period under study. The distinctive literacy characteristics of different religious groups are well documented in the census reports (Marten, 1921; Khan, 1932). The fixed effects $\varphi_{(r, d)}$ account for unobservable determinants of literacy that remain constant over time at the district-religion level.

\subsection{Endogeneity}

For the above main specification to yield causal estimates of the treatment effects, I rely on three assumptions:

1. The recruitment patterns of the Indian army did not change over the course of WWI.

2. The initial selection of recruitment grounds was unrelated to the potential for literacy improvements between 1921 and 1931.

3. The measurement error induced by using war casualties as a proxy for recruitment is non-systematic and small.

\subsubsection{Predetermined recruitment patterns}

It was argued in the historical background that war-time recruitment mainly led to a demand shock for military labor in existing recruitment grounds. At the district level, this assumption can be tested explicitly with Leigh's recruitment statistics (Leigh, 1922, p.61-62), compiled based on local sources in the districts (the District War Histories). The correlation between

use of literacy rates as level, a log-odds specification (which ensures full support of the dependent variable) and the logarithm of the number of male literates (results available on request). 
the share of the eligible population that served during the war and the share that was recruited before the war is 0.93 and presented in figure 2.

Figure 2: Recruitment before and during the war

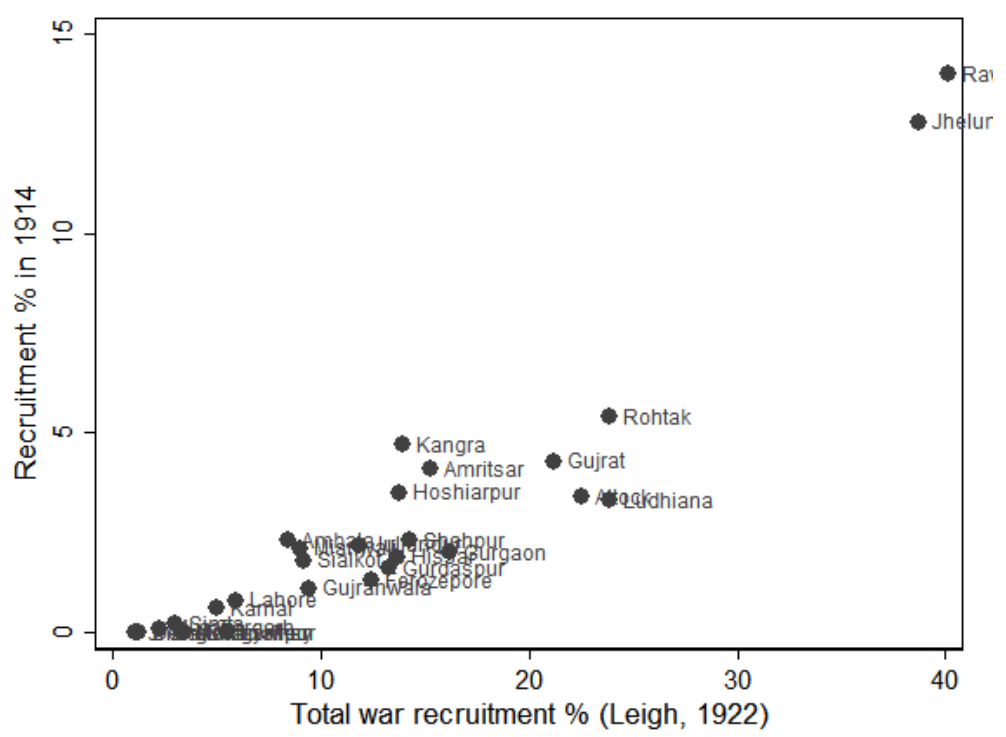

Notes: Observations are for 28 districts. Recruitment shares are expressed as a fraction of the eligible male population according to Leigh (1922).

To support the hypothesis of entrenched recruitment patterns at the district-religion level (my main unit of analysis), Figure 3 plots war deaths before and after 1916 for each districtreligion. As a result of the gradual build-up of the Indian Army, casualty numbers at the start of the war are likely reflect pre-existing recruitment patterns. ${ }^{32}$ The linear pattern in Figure 3 further supports the hypothesis that recruitment patterns at the district-religion level remained stable over the course of the war. ${ }^{33}$

\footnotetext{
${ }^{32}$ At the district level, the correlation between recruitment rates in 1914 and the casualty rates before 1916 is 0.86 .

${ }^{33}$ War deaths before 1916 account for approximately $22 \%$ of all recorded military casualties who originated from Punjab. The correlation between the casualty rates before and after 1916 is 0.89 . $14 \%$ of all war-time soldiers were recruited before 1915 and a further 18\% between January 1915 and April 1916. The remaining $68 \%$ were recruited from April 1916 onwards. About 22\% of all casualties died before January 1916. Hence, the build-up of the army was gradual over the course of the war, and substantial changes in the army's recruitment patterns should be visible in the casualty rates.
} 
Figure 3: Time pattern of casualty shares at the district-religion level

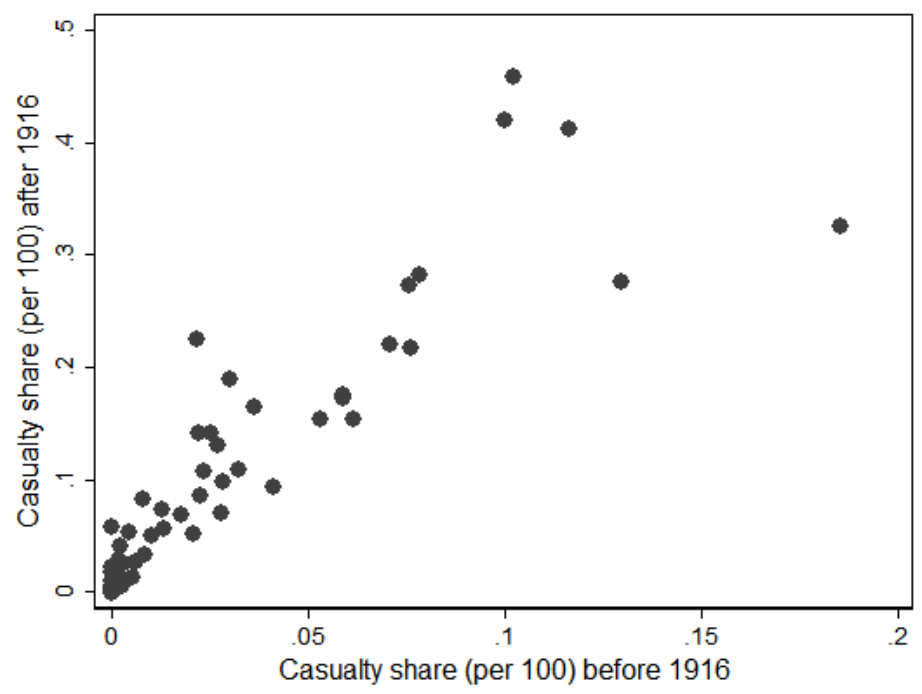

Notes: Observations are at the district-religion level, for 56 groups (Hindu-Sikh and Muslim, in 28 districts). Casualty shares are expressed per 100 of the 1911 male population.

\subsubsection{The common trends assumption}

The second assumption paraphrases the common trend assumption: if they had not been heavily recruited during the war, then the heavily recruited district-religions should have experienced the same literacy growth as lightly recruited district-religions. This assumption is relatively weak and does not require the process that drives recruitment at the community level to be random, although it should be unrelated to literacy improvements over the 19111931 period. The selection of recruitment grounds, the willingness of the population to enlist, and the average suitability of individual candidates may be related to unobservable districtreligion characteristics. However, there is no historical evidence that the British targeted communities that had a higher potential for literacy improvements over the period 1911-31. The historical sources discussed in section 3 point to a multitude of selection criteria that were highly subjective. Given the persistence of recruitment patters, the surge during the war can be considered as an exogenous labor demand shock to this subset of district-religions that had been selected well before the start of the war.

My analysis provides support for the common trend assumption in four ways. Table 1 
and Table 2 fail to find significant differences between heavily and lightly recruited communities/districts for the most relevant district and district-religion level characteristics: baseline literacy, education expenditures, and land revenues. Second, as a robustness check of the main results, I confirm that the results are robust to including time-effects of these baseline controls (these control variables include measures of baseline district-level mortality and per capita land revenues). The consistency of estimates to the inclusion of observable control variables implies that the relative impact of unobservable characteristics needs to be very large to overturn the main results (following the argument of Altonji, Elder, and Taber, 2005). Third, I provide more direct evidence of the validity of the common trend assumption by the (placebo) estimation of a 'pre-treatment' effect that relies on observations between 1901 and 1911. The absence of a pre-treatment effect is particularly powerful because recruitment grounds were established before 1901. Therefore, selection on determinants of literacy improvement should generate a pre-treatment effect. Fourth, I use an IV approach based on the classification of district-religions by recruitment officers. The variation used in the IV estimates should be pre-determined and capture the constraints on the demand for military labor at the district level more than the quality of individual recruits and their willingness to enlist. As the latter factors are more likely to lead to violations of the exclusion restriction, the consistency of the IV estimates supports the empirical approach. Based on these arguments, I rely on a standard continuous difference-in-difference specification for my main results.

\subsubsection{War casualties as recruitment proxies}

The third identifying assumption is that the error resulting from my proxy approach is orthogonal to the regressors. At the district level, this assumption could be tested directly with Leigh's data (as shown in figure 1). While suggestive, the evidence of proportional mortality at the district level does not guarantee that casualty rates are proportional at the district-religion level. Unfortunately, Leigh does not provide recruitment estimates by 
district-religion. Still, a general proportionality of war casualties to recruitment is consistent with the strategic calculus of the Indian Army. Its leadership had an interest in sending representative units (including multiple battalions with a different composition) on its foreign missions (Jha and Wilkinson, 2012). After the Sepoy mutiny, the Indian army made regiments sufficiently heterogeneous to limit the risk of mutiny. Hence, regiments would typically recruit from different districts and religions. Figure 3 already provided implicit support for the proportionality of war casualties to the underlying recruitment patterns at the district-religion level: casualty patterns before and after 1916 look remarkably similar. In further support of my proxy approach, I report the correlation between the casualty rates at the district-religion level for different types of casualties: ${ }^{34}$

- Casualties buried in Western Europe and outside of Western Europe (correlation: 0.92)

- Casualties in regiments with high and low overall mortality (correlation: 0.82)

- Casualties in soldier and higher ranks (correlation: 0.97)

The casualty patterns are remarkably similar for these different groups. The strong correlation between regiments with different overall mortality profiles suggests that Indian army did not try to deploy specific district-religions in more casualty-prone battles. Moreover, the pattern of casualties in different ranks is very similar. Indian soldiers had limited promotion opportunities, as they could only rise to junior officer ranks (Corrigan, 1999). Therefore, literate soldiers (who could have served in higher ranks) should not have faced dramatically different hazards in battle than illiterate soldiers. The online appendix shows that restricting the analysis to soldier ranks does not change the results. For all the reasons put forward in this section, I rely on a proxy approach in the main results. However, to mitigate any remaining concerns related to measurement error, I present IV results that use the assessments of British officers as an instrument for the observed WWI casualty rate. I also check

\footnotetext{
34"High mortality regiments" (figure 6) are in the top $10 \%$ of the regiment-level distribution of the total number of casualties. For each district I construct separate casualty rates for these regiments and I compare them to casualty rates in all other regiments. Soldier ranks (figure 7) include gunners, riflemen, sorwars, and sepoys. See figures 5,6 , and 7 in the online appendix (A.1).
} 
the robustness of the main findings to using recruitment statistics instead of casualty rates at the district level (table 5).

\subsubsection{External validity}

While the empirical approach addresses the key endogeneity concerns, it is harder to make firm statements about the external validity of the effects. At the individual level, the voluntary nature of military service implies that recruits were not representative of their communities: they are likely to have been physically stronger than other group members. Such heterogeneity has implications for the external validity of the results, which could be very different in a context of conscription. ${ }^{35}$ Similarly, (unobserved) heterogeneity between recruited groups may have implications for external validity, even if the common trends assumption holds.

\section{$6 \quad$ Results}

The results from the baseline specification can be found in Table 3. An increase in the casualty rate by 0.1 per 100 of the male population is associated with an increase in the literacy rate by 4.7 per cent (proportional). This implies that for 1 additional recruit per 100 of the male population, the literacy rate increases by 2.4 per cent in $1931 .^{36}$ Evaluated at the sample mean, this corresponds to an increase of 2.6 additional literate males per thousand of the male population. The further increase in the literacy rate in 1931 is consistent with the fact that complete demobilization was only reached after 1921. The estimated returns to military service are large in economic terms. Given that the public education system

\footnotetext{
${ }^{35}$ Bodenhorn, Guinnane, and Mroz (2014) develop and occupational choice model between civilian and military labor to explain variation in the height of recruits. Applied to literacy, their argument about height would suggest that the number of literate recruits might reflect local economic conditions. The effect of military recruitment on literacy could differ depending on the share of literate recruits, although average literacy was very low and most recruits were illiterate (as discussed in section 3).

${ }^{36} \mathrm{I}$ assume an equal probability of dying and divide the number of Punjabi men recruited (app. 360,000) by the number of Punjabi war deaths (app. 19,000) to obtain an estimate of the number of recruited soldiers corresponding to one war death (18.94).
} 
struggled to improve adult literacy (Chaudhary, 2010), the positive effects of military service are particularly striking.

Table 3 also confirms that military recruitment did not have an impact on the size of the population, which addresses the concern that the observed effects on literacy rate are driven by changes in the denominator. Moreover, given that the impact on the size of the population is positive, it is clear that the effect of war casualties on the number of literates is positive as well (because of the log specification, the total effects are given by the sum of the coefficients columns 1 and 4,2 and 5, and 3 and 6, and these retain their significance for the relevant coefficients). As a result, higher mortality of illiterates in more heavily recruited districts cannot account for the main findings.

\section{Table 3: Baseline specification}

\begin{tabular}{lcccccc}
\hline \hline & \multicolumn{2}{c}{$\log ($ male literacy rate $)$} & \multicolumn{3}{c}{$\log ($ male population) } \\
& $\begin{array}{c}\text { All ages } \\
(1)\end{array}$ & $\begin{array}{c}\text { Over } 20 \\
(2)\end{array}$ & $\begin{array}{c}\text { Under } 20 \\
(3)\end{array}$ & $\begin{array}{c}\text { All ages } \\
(4)\end{array}$ & $\begin{array}{c}\text { Over 20 } \\
(5)\end{array}$ & $\begin{array}{c}\text { Under } 20 \\
(6)\end{array}$ \\
\hline Casualty rate & $0.33^{* *}$ & $0.40^{* *}$ & 0.06 & 0.13 & 0.13 & 0.14 \\
$* 1921$ & $(0.16)$ & $(0.15)$ & $(0.21)$ & $(0.17)$ & $(0.17)$ & $(0.17)$ \\
Casualty rate & $0.47^{*}$ & $0.50^{* *}$ & 0.30 & 0.10 & 0.10 & 0.09 \\
$* 1931$ & $(0.24)$ & $(0.20)$ & $(0.33)$ & $(0.19)$ & $(0.19)$ & $(0.20)$ \\
Observations & 168 & 168 & 168 & 168 & 168 & 168 \\
\hline
\end{tabular}

Notes: District-religion level observations for 56 groups (Muslim or Hindu-Sikh, in 28 districts), for three census years (1911-31). Casualty rates are expressed per 100 of the 1911 male population. All regressions include district-religion fixed effects and religion-year effects. Standard errors are clustered at the district-religion level. ${ }^{* * *} \mathrm{p}<0.01,{ }^{* *} \mathrm{p}<0.05,{ }^{*} \mathrm{p}<0.1$.

Table 3 also provides the first piece of evidence on the mechanism. In columns (2) and (3), the baseline regression is run for two age groups separately: over-20-year-old males and under-20-year-old males. ${ }^{37}$ While military war deaths are not associated with significant lit-

\footnotetext{
${ }^{37}$ One caveat on this analysis is that a proportion of respondents would typically not know their age (Chaudhary, 2010). Literacy for over-30-year-olds is not reported by the census, which prevents a cohortlevel analysis. In the appendix (A.3.5), I discuss an approach to estimate (approximated) cohort-specific literacy gains.
} 
eracy improvements for the under-20-year-olds (column 3), the over-20-year-olds in recruited communities improved their literacy significantly relative to other communities (column 2). The difference between these two effects in 1921 is significant at the $1 \%$ level (columns 2 and 3), but becomes insignificant in 1931. The fact that over-20-year-olds are driving the short run impact supports the hypothesis that direct skill acquisition is a key mechanism through which military recruitment improved literacy. If the improvements in literacy are driven by the return of demobilized soldiers to their home communities, then we should only expect literacy to improve for men above military age and the impact should be visible immediately after the war (in 1921). If communities experienced higher literacy in response to the inflow of military salaries, one would expect to see an effect that is stronger for (if not limited to) under-20-year olds, as this group has the lowest opportunity cost of acquiring literacy skills through education. The fact that under- and over-20-year olds do not experience significantly different literacy gains in 1931 is consistent with the presence of mild spill-overs, although the effect is not sufficiently strong (or precise) to make the impact on under-20-year olds significant.

The key identification assumption underlying these results is that war casualties are unrelated to the counterfactual literacy growth in the absence of war recruitment. As discussed in detail in the endogeneity section, this assumption is weaker than randomness in recruitment or casualty patterns, and can be supported by looking at literacy trends before the war. Table 4 restricts the sample to allow for the estimation of a 'pre-treatment effect'. The pre-treatment effect on the male literacy rate is estimated to be insignificant and close to zero, which supports the common trends assumption. ${ }^{38}$

\footnotetext{
${ }^{38}$ Even columns include year-effects for the 7 districts with canal colonies, which experienced high immigration between 1901 and 1911 (Agnihotri, 1996).
} 
Table 4: Pre-treatment effect

\begin{tabular}{|c|c|c|c|c|c|c|}
\hline & \multicolumn{6}{|c|}{ Log(male literacy rate) } \\
\hline & \multicolumn{2}{|c|}{ All ages } & \multicolumn{2}{|c|}{ Over 20} & \multicolumn{2}{|c|}{ Under 20} \\
\hline & (1) & $(2)$ & $(3)$ & (4) & $(5)$ & (6) \\
\hline $\begin{array}{l}\text { Casualty rate } \\
*^{*} 1911\end{array}$ & $\begin{array}{c}0.02 \\
(0.11)\end{array}$ & $\begin{array}{l}-0.00 \\
(0.12)\end{array}$ & $\begin{array}{c}0.10 \\
(0.11)\end{array}$ & $\begin{array}{c}0.09 \\
(0.13)\end{array}$ & $\begin{array}{l}-0.13 \\
(0.22)\end{array}$ & $\begin{array}{l}-0.22 \\
(0.23)\end{array}$ \\
\hline $\begin{array}{l}\text { Casualty rate } \\
\text { *1921 }\end{array}$ & $\begin{array}{l}0.32^{*} \\
(0.17)\end{array}$ & $\begin{array}{c}0.26 \\
(0.17)\end{array}$ & $\begin{array}{c}0.47^{* * *} \\
(0.15)\end{array}$ & $\begin{array}{c}0.39 * * \\
(0.16)\end{array}$ & $\begin{array}{l}-0.09 \\
(0.28)\end{array}$ & $\begin{array}{l}-0.13 \\
(0.28)\end{array}$ \\
\hline $\begin{array}{l}\text { Casualty rate } \\
\text { *1931 }\end{array}$ & $\begin{array}{c}0.41 \\
(0.26)\end{array}$ & $\begin{array}{l}0.56^{*} \\
(0.28)\end{array}$ & $\begin{array}{l}0.52^{* *} \\
(0.22)\end{array}$ & $\begin{array}{c}0.64^{* * *} \\
(0.22)\end{array}$ & $\begin{array}{c}0.07 \\
(0.40)\end{array}$ & $\begin{array}{c}0.27 \\
(0.44)\end{array}$ \\
\hline \multicolumn{7}{|l|}{ Colony-year } \\
\hline Observations & 208 & 208 & 208 & 208 & 208 & 208 \\
\hline $\begin{array}{l}\text { Notes: Distric } \\
\text { districts), for } \\
\text { religion-year } \\
\text { analysis beca } \\
\text { district-religic }\end{array}$ & $\begin{array}{l}\text { igion le } \\
\text { census } \\
\text { s, and c } \\
\text { f substa } \\
\text { vel. *** }\end{array}$ & $\begin{array}{l}\text { oservati } \\
(1901-3 \\
\text {-year e } \\
\text { border } \\
01,{ }^{* *}\end{array}$ & $\begin{array}{l}\text { or } 52 \text { con } \\
\text { All regres } \\
\text { Rawalp } \\
\text { ges. Star } \\
05,{ }^{*} \mathrm{p}<0\end{array}$ & $\begin{array}{l}\text { iities (M } \\
\text { include } \\
\text { and Att } \\
\text { errors }\end{array}$ & $\begin{array}{l}\text { or Hinc } \\
\text { ct-relig } \\
\text { e omitt } \\
\text { stered }\end{array}$ & $\begin{array}{l}\text { h, in } 26 \\
\text { xed effects } \\
\text { m this }\end{array}$ \\
\hline
\end{tabular}

\subsection{Robustness}

\subsubsection{District level results}

In Table 5, the main regression is presented at the district level. These results line up very well with the district-religion level results, in spite of important differences in the recruitment of different religious groups within the same district. The district-level analysis allows for two important robustness checks. First, I can test whether the main results go through for Leigh's recruitment estimates at the district level. These results (in even columns) are very similar to the main results based on casualty patterns, ${ }^{39}$ and indicate that selective war mortality is not driving the main results. Second, the district level allows me to control explicitly for confounding factors in Table 6. I include both time effects for baseline controls

\footnotetext{
${ }^{39}$ Taking into account that the eligible male population (used in the recruitment shares) is around $40 \%$ of the total male population and the mortality rate in the Army is $1 / 19$, the implied estimates are quantitatively similar: 2 additional male literates in 1931 for every recruit (column 1 and 2).
} 
(columns 1,2,4,5,7,8) and additional contemporary controls (columns 3,6,9). The set of controls includes a wide range of potential confounding factors: canal colony status, per capita land revenues at baseline, the share of the agricultural population, contemporaneous migration, and mortality at baseline (the last measure is only available in a smaller sample of 21 districts). In the online appendix (table 16), I further confirm that the district-religion level results are broadly robust to the inclusion of district-year fixed effects. Therefore, it appears unlikely that the observed effects of war recruitment are driven by unobserved characteristics at the district-level.

\section{Table 5: District level results}

\begin{tabular}{|c|c|c|c|c|c|c|}
\hline & \multicolumn{6}{|c|}{ Log(male literacy rate) } \\
\hline & \multicolumn{2}{|c|}{ All ages } & \multicolumn{2}{|c|}{ Over 20} & \multicolumn{2}{|c|}{ Under 20} \\
\hline & (1) & $(2)$ & $(3)$ & $(4)$ & $(5)$ & (6) \\
\hline Casualty rate & $0.46^{* *}$ & & $0.53^{* * *}$ & & 0.24 & \\
\hline *1921 & $(0.17$ & & $(0.162)$ & & $(0.19)$ & \\
\hline Casualty rate & $0.48^{*}$ & & $0.48^{* *}$ & & 0.42 & \\
\hline$* 1931$ & $(0.24)$ & & $(0.23)$ & & $(0.30)$ & \\
\hline Recruitment rate & & $0.58^{* *}$ & & $0.66^{* * *}$ & & 0.30 \\
\hline$* 1921$ & & $(0.22)$ & & $(0.22)$ & & $(0.23)$ \\
\hline Recruitment rate & & $0.78^{* *}$ & & $0.76^{* *}$ & & $0.76^{*}$ \\
\hline *1931 & & $(0.319)$ & & $(0.328)$ & & $(0.394)$ \\
\hline Observations & 168 & 168 & 168 & 168 & 168 & 168 \\
\hline \multicolumn{7}{|c|}{$\begin{array}{l}\text { Notes: observations are at the district level for three census years (1911-31). Casualty rates } \\
\text { are expressed per } 100 \text { of the male population, and recruitment rates as a share of the total } \\
\text { eligible male population. District fixed effects and colony-year effects are included in all } \\
\text { columns. See } 2 \text { for summary statistics. Standard errors are clustered at the district level. }{ }^{* * *} \\
\mathrm{p}<0.01,{ }^{* *} \mathrm{p}<0.05,{ }^{*} \mathrm{p}<0.1\end{array}$} \\
\hline
\end{tabular}

\subsubsection{An IV approach}

A remaining concern in the analysis presented so far is the possibility that shocks between 1911 and 1921 explain both war-time recruitment and literacy outcomes. As argued earlier, the recruitment patterns of the Indian Army are surprisingly consistent over the war period, 


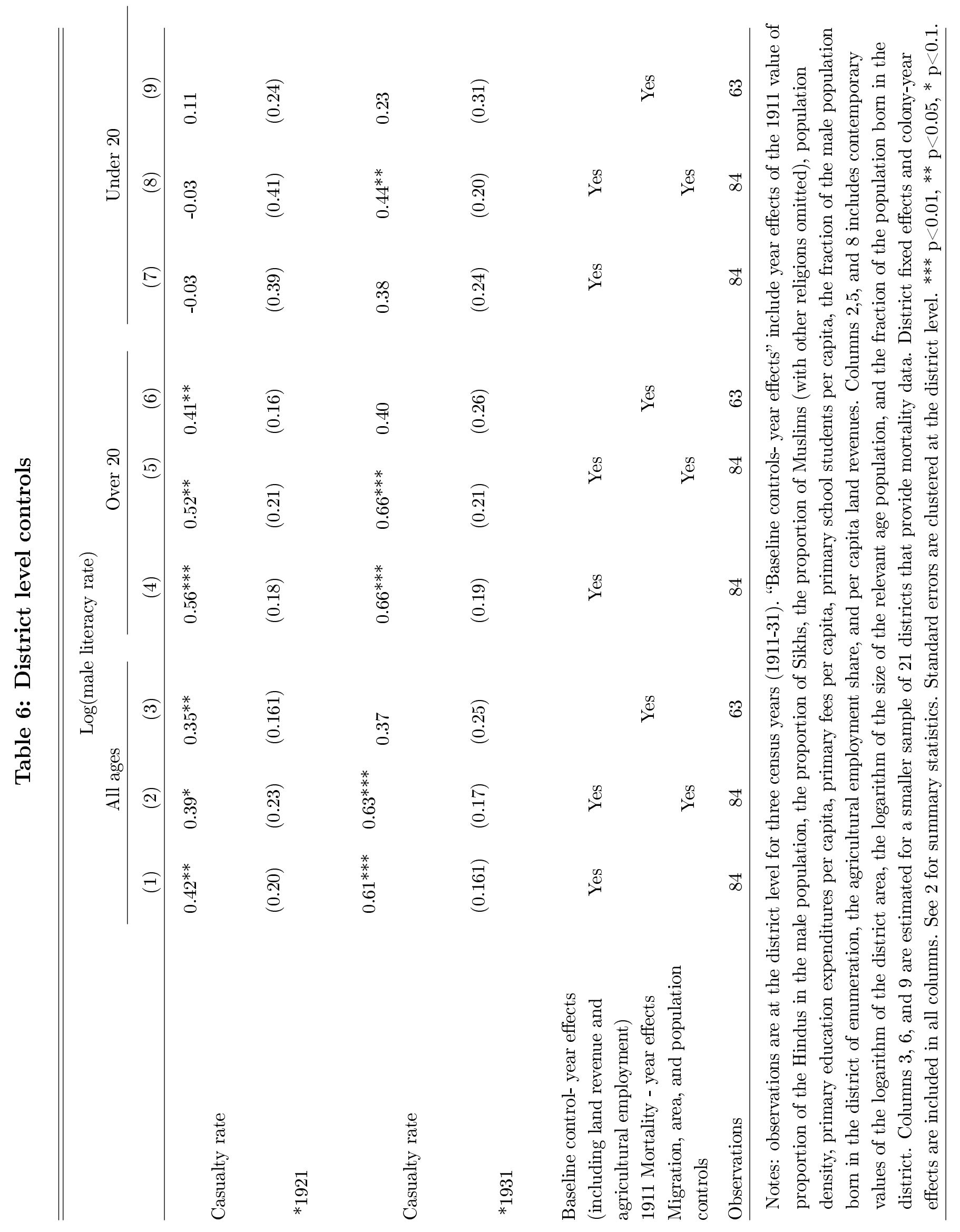


but I cannot track recruitment between 1911 and 1914. Also, the validity of using war casualties as recruitment proxies could not be confirmed at the district-religion level. The IV approach tries to address these two concerns. It will also have the advantage of focusing on the demand-side constraints that underlie recruitment patterns. In particular, I use the classifications of British recruitment officers as a fully predetermined predictor of war-time recruitment. My key source of information is a set of publications by Captain A. H. Bingley (who published detailed handbooks for the recruitment of Sikhs in 1899 and Dogra Hindus in 1897), Lieutenant Colonel J.M. Wikeley (who published on Muslims in Western Punjab in 1915), and Colonel W.F. Bourne (who published a similar handbook for Muslim recruitment in Eastern Punjab in 1914). ${ }^{40}$ Based on their classifications, I construct an indicator variable to measure "recruitment suitability". For recruitment suitability to be a valid instrument, it needs to be correlated with the proxy for military recruitment and it cannot influence the observed literacy pattern through any other channel than through military recruitment as proxied by war deaths. As discussed in section 2 (p.11), the selection criteria used to mark communities as good recruitment grounds included subjective assessments of physique, being used to hard agricultural labor, a history of warfare, caste pride, obedience, not being "quarrelsome". Because these assessments were made before the start of the First World War, the diff-in-diff-IV estimates will not be driven by short-run shocks to literacy.

The information provided by the recruitment handbooks differs for each religion/caste. For Sikhs, Bingley reports a ranking of tahsils (sub-districts) based on their suitability for military recruitment. For Dogra recruits, information is available on which tahsils make the "best" recruitment grounds. For Muslims, Bourne and Wikeley explicitly mention certain tahsils as being good recruitment grounds for particular groups. I construct a recruitment suitability measure at the district-religion level that equals the share of tahsils within each district that are classified as good recruitment grounds for that religious group. For a Hindu community in a given district I look at the share of tahsils in the district (1) listed as "the

\footnotetext{
${ }^{40}$ Even though Bourne and Wikely published their works at the start of the War (in 1914 and 1915 respectively), their most recent references are from 1912 and they do not mention the war at any point.
} 
best" Dogra recruitment grounds, or (2) listed as having "Very good" Sikh recruits. The value for the Muslim community in the same district will be based on the share of tahsils mentioned as recruitment grounds by Bourne or Wikeley. ${ }^{41}$ The resulting first stage regression is given by:

$$
\text { Cas }_{r, d, 11}=\lambda_{0}+\lambda_{1} \text { suitability }_{r, d, 11}+\varepsilon_{d, 11}
$$

A 2SLS regression of the change in literacy rates relative to 1911 is run separately for 1921 and 1931.

$$
\triangle y=\varphi+\beta \widehat{\operatorname{cas}}_{r, d, 11}+v_{d}
$$

Table 7 presents the results of the IV approach (using a LIML estimator). The first stage in column (3) confirms the relevance of the instrument. In the IV LIML results, the coefficient on the casualty rate retains its significance in spite of large standard errors, but its magnitude is substantially higher than for the OLS results. Of course, the instrumentation approach is only valid if the initial selection of recruitment grounds is exogenous. I cannot fully rule out the possibility that recruitment officers selected communities on criteria that led to subsequent literacy development. Hence, this robustness check mainly addresses the endogeneity concerns that relate to the proxy approach and endogenous selection into the army due to time-varying factors during the First World War. However, the IV results are consistent with attenuation bias being the main endogeneity concern. Moreover, I can check the sensitivity of the IV estimates using the method developed by Conley, Hansen, and Rossi (2012). These results are presented in the online appendix (figures 9 and 10 on p.17) and confirm the robustness of the IV results to small departures from perfect exogeneity.

\footnotetext{
${ }^{41}$ Bingley (1899, p.108) considers the tahsil to be the best unit of geographical targeting. The average suitability score is 0.19 , the average score is 0.13 for Hindu-Sikhs and 0.24 for Muslims. The results are robust to using the measures of the three religious groups as separate instruments.
} 


\section{Table 7: IV results}

\begin{tabular}{|c|c|c|c|c|c|}
\hline & \multicolumn{5}{|c|}{$\begin{array}{l}\text { Casualty } \\
\text { rate } \quad \triangle \log (\text { MaleLiteracyrate })\end{array}$} \\
\hline & \multirow{2}{*}{$\begin{array}{l}\text { (per 100) } \\
\text { First Stage } \\
(1)\end{array}$} & \multicolumn{2}{|c|}{ All ages } & \multirow{2}{*}{$\begin{array}{c}\text { Over } 20 \\
\text { IV (LIML) } \\
(5)\end{array}$} & \multirow{2}{*}{$\begin{array}{c}\text { Under } 20 \\
\text { IV (LIML) } \\
(7)\end{array}$} \\
\hline & & $\begin{array}{c}\text { OLS } \\
(2)\end{array}$ & $\begin{array}{l}\text { IV (LIML) } \\
(3) \\
\end{array}$ & & \\
\hline Casualty rate*1921 & & $\begin{array}{c}0.33^{* *} \\
(0.16)\end{array}$ & $\begin{array}{l}0.42^{*} \\
(0.23)\end{array}$ & $\begin{array}{c}0.51^{* *} \\
(0.23)\end{array}$ & $\begin{array}{c}0.13 \\
(0.35)\end{array}$ \\
\hline Casualty rate*1931 & & $\begin{array}{l}0.47^{*} \\
(0.24)\end{array}$ & $\begin{array}{l}0.61^{*} \\
(0.33)\end{array}$ & $\begin{array}{c}0.60^{* *} \\
(0.28)\end{array}$ & $\begin{array}{c}0.56 \\
(0.48)\end{array}$ \\
\hline $\begin{array}{l}\text { Share of "very good" } \\
\text { tahsils }\end{array}$ & $\begin{array}{l}0.34^{* * *} \\
(0.07)\end{array}$ & & & & \\
\hline F-statistic & 24.9 & & & & \\
\hline Observations & 56 & 56 & 56 & 56 & 56 \\
\hline
\end{tabular}

\section{Mechanisms}

In this section I will present a set of secondary results that help to uncover the mechanism behind the main results. First, I show data on public education, the number of students, and the volume of letters. Then, I also show results on female and English literacy. All these additional results turn out to be consistent with an informal learning mechanism that benefited veterans directly.

\subsection{Public education, students, and letters}

To investigate whether investments in education by the District Boards are driving my results, this section analyzes the role of education expenditures. These investments were specific to British districts and official statistics do not distinguish between religious groups. 
Two outcome variables are considered: total primary school expenditures and the number of native-language students enrolled in public and private schools. If recruited districts were successful in attracting more educational investment by the local authorities after the war, one would expect a positive effect on these expenditures. If military service created a demand shock for education, this should be reflected in the number of students. As school expenditure and student data are only available at the district level, the variables of interest were aggregated at the district level instead of at the district-religion level.

Table 8 relies on the main specification (now estimated at the district level) to examine the association between military war deaths and primary education expenditures. ${ }^{42}$ Column (1) of Table 8 shows that the evolution of spending on primary education bears little relationship to the proportion of military war deaths to the 1911 population. If anything, heavily recruited districts spent less on primary schooling after the war. This finding goes against the hypothesis that the colonial authorities targeted education spending to heavily recruited districts. To the contrary, the Government of India may have feared that too much educational investment in the recruitment zones could undermine the recruitment potential of these regions by improving the outside options of prospective soldiers. Column (2) presents a difference-in-difference analysis of student enrolment between 1914 and 1921 and shows a negative but non-significant impact of military recruitment on the number of students in vernacular primary schools (both in public and private education). ${ }^{43}$

\footnotetext{
${ }^{42}$ Chaudhary $(2009,2010)$ argues that literacy in colonial India mainly depended on access to primary schools.

${ }^{43}$ Student enrolment data are not available after 1922. The relationship between the casualties and literacy holds for the subsample of 20 districts that provide enrolment data for 1921 (not reported).
} 
Table 8: Investments in education

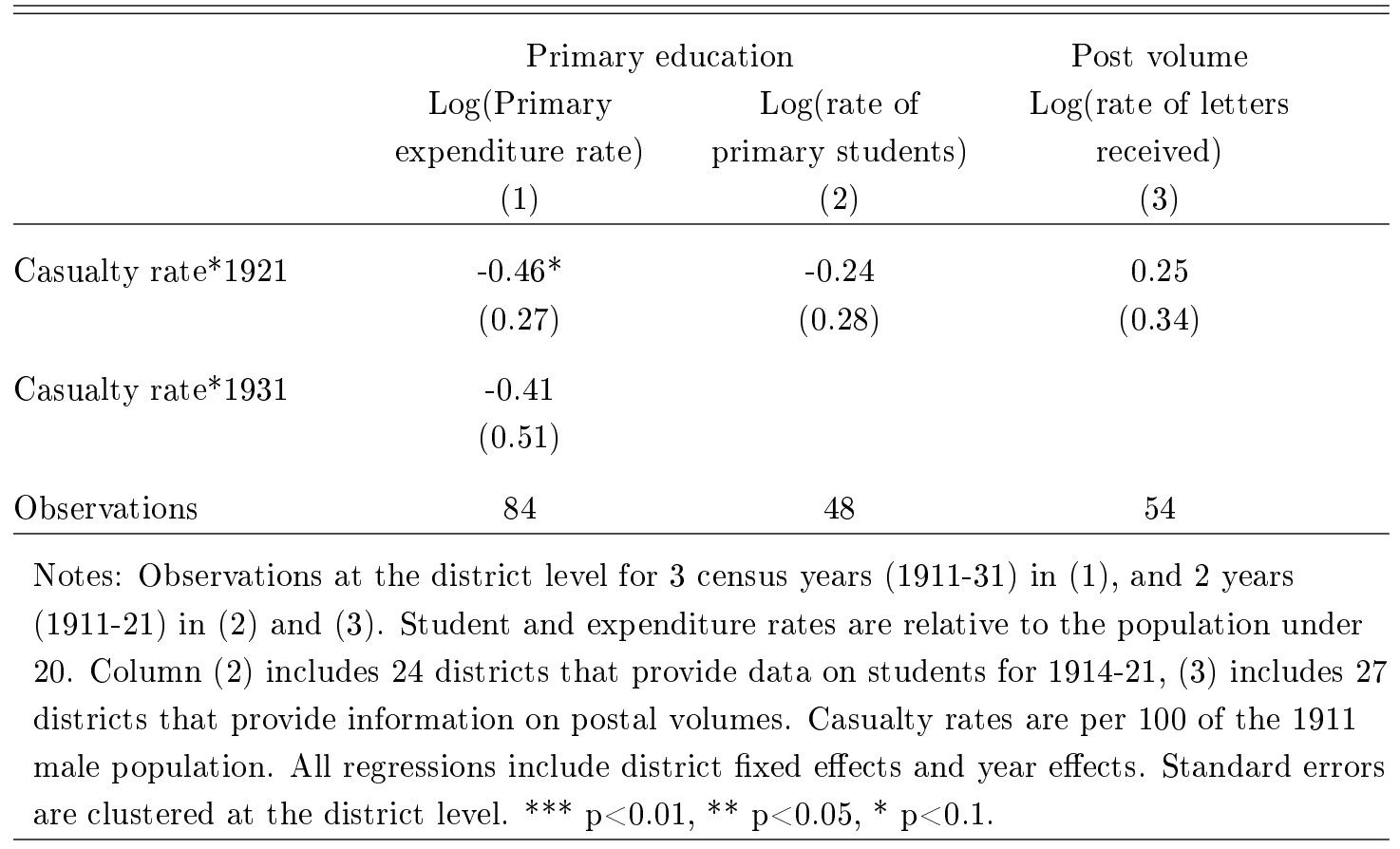

\section{Table 9: Controlling for education (district level)}

\begin{tabular}{|c|c|c|c|c|c|c|}
\hline & \multicolumn{6}{|c|}{ Log(male literacy rate) } \\
\hline & \multicolumn{2}{|c|}{ All ages } & \multicolumn{2}{|c|}{ Over 20} & \multicolumn{2}{|c|}{ Under 20} \\
\hline & $(1)$ & $(2)$ & $(3)$ & $(4)$ & $(5)$ & (6) \\
\hline Casualty rate & $0.46^{* *}$ & $0.53^{* * *}$ & $0.50^{* * *}$ & $0.53^{* *}$ & $0.33^{*}$ & 022 \\
\hline *1921 & $(0.17)$ & $(0.17)$ & $(0.17)$ & $(0.16)$ & $(0.17)$ & $(0.25)$ \\
\hline Casualty rate & $0.48^{*}$ & $0.50^{*}$ & $0.46^{*}$ & $0.48^{*}$ & $0.51^{*}$ & $0.41^{*}$ \\
\hline$* 1931$ & $(0.24)$ & $(0.28)$ & $(0.23)$ & $(0.23)$ & $(0.29)$ & $(0.35)$ \\
\hline Log(Primary & 0.00 & & -0.06 & & $0.20^{*}$ & \\
\hline *expenditure rate) & $(0.08)$ & & $(0.06)$ & & $(0.10)$ & \\
\hline \multicolumn{7}{|l|}{1911 Primary } \\
\hline expenditures - year effects & & Yes & & Yes & & Yes \\
\hline \multicolumn{7}{|l|}{1914 student share - year } \\
\hline effects & & Yes & & Yes & & Yes \\
\hline Observations & 84 & 84 & 84 & 84 & 84 & 84 \\
\hline \multicolumn{7}{|c|}{$\begin{array}{l}\text { Notes: Observations at the district level for three census years (1911-31). Casualty rates are } \\
\text { per } 100 \text { of the } 1911 \text { male population, student and expenditure rates are relative to the } \\
\text { population under } 20 \text {. All regressions include district fixed effects and year effects. Standard } \\
\text { errors are clustered at the district level. }{ }^{* * *} \mathrm{p}<0.01,{ }^{* *} \mathrm{p}<0.05,{ }^{*} \mathrm{p}<0.1 \text {. }\end{array}$} \\
\hline
\end{tabular}


The hypothesis that public investment in education is not driving earlier findings is further confirmed in Table 9. The findings from this specification are in line with earlier results, even though the analysis is now conducted at the district level. ${ }^{44}$ In the odd columns, contemporaneous spending on primary education is included as a control variable. The even columns allow for initial investment in education (in 1911) and student enrolment rates (in 1914) to have a year-specific effect on literacy outcomes. This specification addresses the concern that recruited districts had already attracted preferential investments in education before the war.

In column (3) of table 8, I estimate the impact of military recruitment on the volume of letters. While this effect is positive, it does not gain significance. Unfortunately, the postal data are likely to be very imprecise, as they were based on annual samples of two weeks, and there is no data on the volume of letters sent during the war (which would be the key variable of interest). The most convincing evidence on the importance of the postal service is historical in nature, and the letters sent by Indian soldiers were referred to earlier in the mechanisms section.

In conclusion, the results on public expenditures on education indicate that education expenditures are unlikely to drive the positive relationship between military recruitment and literacy improvements after the war. Nevertheless, this analysis does suffer from certain limitations. The data collected on students does not distinguish between religions, nor do the data on schools. Not only do these limitations prevent me from disaggregating literacy as in earlier results, I also cannot explore the role of specific institutions such as Madrasas or Dayanand Anglo-Vedic schools (Jones, 1976), although these reached a very limited number of students (Nurullah and Naik, 1951).

\footnotetext{
${ }^{44}$ As the control variables considered in this section only vary at the district level, I use the district-level average literacy rate as the dependent variable. However, the coefficients on war casualties are similar (and more precisely estimated) when these regressions are run at the District-Religion level.
} 


\subsection{Female literacy and English literacy}

The analysis can be extended to female literacy. In table 10, I present summary statistics for female literacy and male English literacy. The average level of female literacy is extremely low (around 1\%). These very low literacy rates give rise to additional measurement concerns. Subject to this caveat, table 10 presents the baseline results for female literacy. The estimated impact of military recruitment on female literacy is negative. This result offers support for the hypothesis that the loss of male labor increases the opportunity cost of women in education, although the estimated impact (evaluated at the sample mean) is negligible from an economic perspective. Still, the negative coefficients are consistent with a scenario in which direct skill acquisition by male soldiers is the key channel that explains improvements in male literacy in recruited communities. ${ }^{45}$

Literacy in English was marginal in colonial Punjab and well below 1\%. While soldiers could have acquired literacy skills in English (Khan, 1932, p216), the lower level fighting units (companies of around 120 soldiers) were linguistically homogeneous and were led by Indian NCOs who spoke the same language. Even British officers were required to learn the Indian vernaculars of the troops they led (Corrigan, 1999, p.9). Moreover, for soldiers, the personal returns to literacy should be much stronger for the vernaculars. Therefore, it is consistent with an informal learning mechanism that table 10 (column 4) does not uncover improvements in English literacy at the aggregate level.

\footnotetext{
${ }^{45}$ While the results on female literacy could be interpreted as a "placebo" test of the direct skill acquisition channel (which should only affect males), this interpretation is subject to an important caveat. Chaudhary (2010) finds that female literacy is less responsive to educational investments than male literacy. Hence, the differential impact on male and female literacy is not necessarily evidence against the income channel or supply-side channel. Besides, the provision of a postal service to serving soldiers could have spill-overs on women.
} 


\section{Table 10: Female and English literacy}

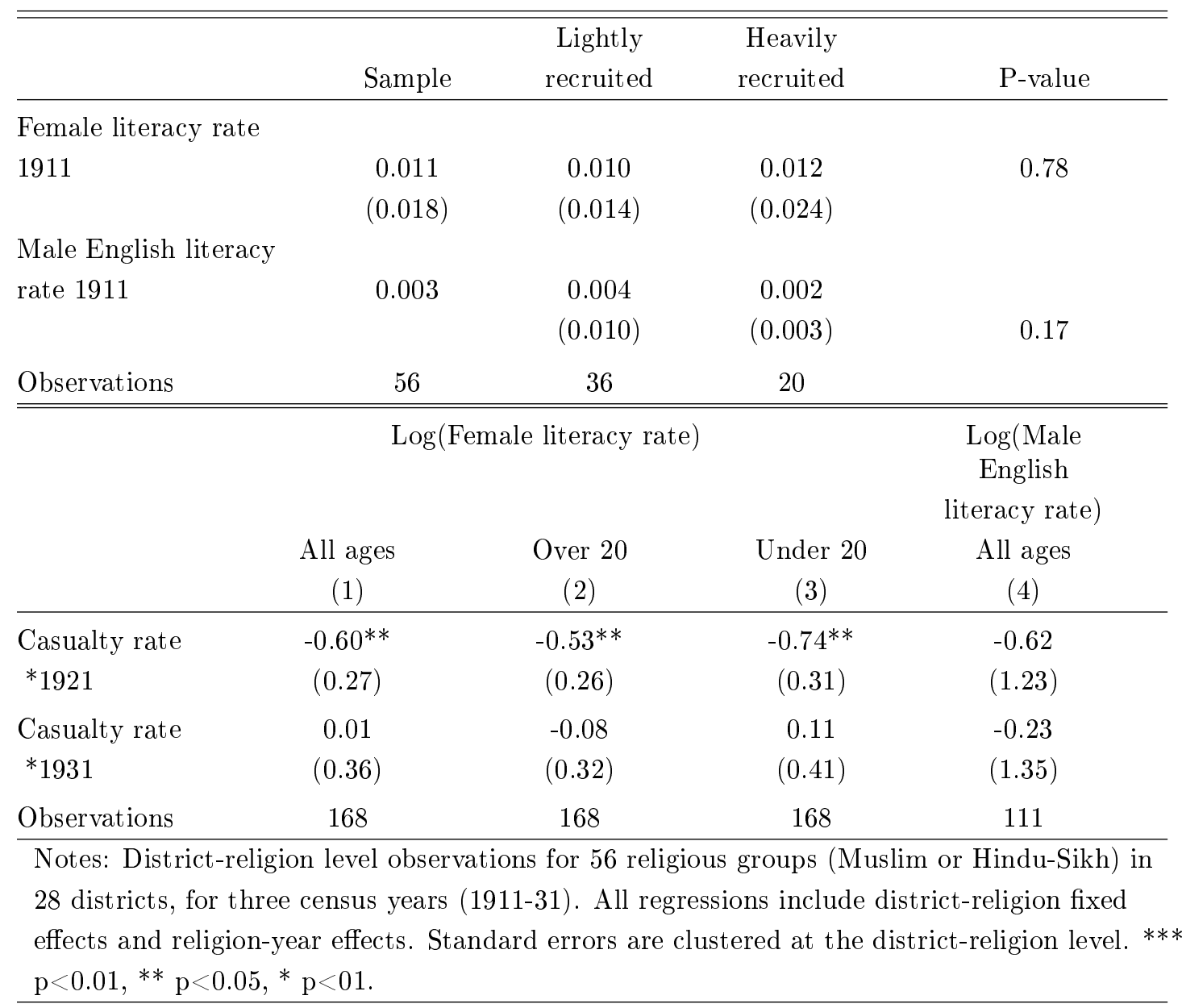

\subsection{Review of mechanisms}

The results presented in this section seem most consistent with direct skill acquisition through informal learning by serving soldiers. While the aggregate impact could include spill-overs to wider community (as I do not observe the literacy among veterans), the magnitudes are consistent with improvements that are limited to soldiers. ${ }^{46}$ There is some evidence of intergenerational spill-overs, but the effects for under-20 year olds are imprecisely estimated.

\footnotetext{
${ }^{46}$ For completeness, it should be pointed out that the causal effect could entirely be driven by non-veterans. The effect could even be indirect: if the temporary absence of aggressive men encouraged the remaining men to pick up literacy skills, they could account for the observed impacts. While this interpretation appears far-fetched, it cannot be ruled out based on the empirical findings.
} 
This imprecision could reflect the importance of unobserved factors in determining whether improvements in adult literacy also translate into intergenerational spill-overs. ${ }^{47}$ Further analysis suggested that recruited districts were not directly targeted by investments in education, nor is there evidence of stronger demand for education in the recruited districts. Moreover, the impacts did not extend to female literacy or literacy in English. All these findings are consistent with informal learning by serving soldiers. A clear limitation of this paper is that I cannot address to which extent these results are specific to war-time military service, and certain channels could be strengthened in this context, although it is worth pointing out that soldiers typically live in military units, away from their families, even in peace-time. In support of this idea, Bingley (1899) discusses the positive impacts of military service on literacy well before the First World War:

"[The Sikhs] who enter the army, manage after a time to acquire enough of the Gurmukhi character to indite a simple and not easily deciphered epistle to their homes, and to spell out, with difficulty, a similar effusion from their friends."

\section{Conclusion}

This paper exploits the exogenous increase in military recruitment during the First World War to estimate the impact of military service on human capital accumulation. My results suggest that ten additional recruits per thousand of the 1911 male population were on average associated with three more literate males per thousand in 1931 (at the sample mean). Further analysis indicates that the improvement in the human capital stock was mainly driven by informal skill acquisition. There is weak evidence that military recruitment also raised the literacy rate of children, in particular in 1931, but this result is not robust across specifications. However, no evidence could be found of preferential spending on primary edu-

\footnotetext{
${ }^{47}$ It is impossible to estimate the long-term persistence of the literacy gains. The Partition of India in 1947 divided Punjab, and it led to the migration and deaths of millions of people (Bharadwaj et al., 2008a,b). As WWII veterans played a role in organizing Partition violence (Jha and Wilkinson, 2013) and the migration affected literates differently (Bharadwaj et al., 2008b), present-day outcomes cannot convincingly be linked to recruitment in WWI.
} 
cation in heavily recruited districts nor do I observe an increase in the number of students at the district level.

There were high costs to the observed improvements in literacy. My estimates suggest that for every six additional literates per thousand one Punjabi soldier gave his life. The fact that volunteer soldiers made this implicit trade-off is suggestive of harsh economic conditions. It also highlights limitations of the current paper, which cannot measure long-term health outcomes for veterans.

During World War 1, the Indian Army provided an environment in which the personal returns to education (including the ability to communicate with one's family) were boosted and the costs of acquiring literacy skills were reduced. While written letters may have lost importance, present-day soldiers could still have incentives to learn to read and write for leisure or for communication with their families. Also, armies could still offer access to lowcost learning methods and a social environment that is conducive to learning. It is intuitive that these channels are most powerful in a context of underinvestment in public education. While the context of war-time recruitment in colonial Punjab is extraordinary, this paper is one of the first to estimate the returns to professional military service when average literacy is very low. Without claiming the generalizability of my findings to present-day examples, it is interesting to note that certain countries are still characterized by high recruitment into professional armies and very low average human capital levels. This is the case of Afghanistan, where $80 \%$ of the Army recruits are thought to be illiterate, or Ethiopia, where $40 \%$ of army recruits reportedly lack any education. ${ }^{48}$ Geographically closer to the context of this paper, military recruitment policies are regularly discussed in the Indian Parliament. The idea that army recruitment could be a tool for redistribution often emerges in these discussions. Times have changed dramatically since World War 1, but in colonial Punjab at least military recruitment brought (unintended) educational benefits.

\footnotetext{
${ }^{48}$ BBC News (2011). In a sample of (voluntary) Ethiopian Army recruits (used for a study of HIV prevalence), Abebe et al. (2003) report that more than $40 \%$ of respondents did not have any education. Their study mentions physique as a recruitment criterion, but not educational attainment. Conscription armies (e.g., Bresil, Iran, Turkey) also do not impose educational minimum standards.
} 


\section{References}

[1] Abebe, Yigeremu, Ab Schaapa, Girmatchew Mamo, Asheber Negussie, Birke Darimo, Dawit Woldaya, and Eduard J. Sandersa. 2003. "HIV in 72000 urban and rural male army recruits, Ethiopia". AIDS, 17(12).

[2] Acemoglu, Daron, Simon Johnson and James A. Robinson. 2001. "The Colonial Origins of Comparative Development: An Empirical Investigation", American Economic Review, 91,p. 1369-1401.

[3] Agnihotri, Indu. 1996. "Ecology, land use and colonisation: The canal colonies of Punjab". Indian Economic Social History Review, 33(1).

[4] Aker, Jenny, Christopher Ksoll and Travis Lybbert. 2011. "ABC, 123: The Impact of a Mobile Phone Literacy Program on Educational Outcomes.", mimeo Tufts University.

[5] Altonji, Joseph G., Todd E. Elder, and Christopher R. Taber. 2005. "Selection on Observed and Unobserved Variables: Assessing the Effectiveness of Catholic Schools." Journal of Political Economy, 113(11): 151-184.

[6] Angrist, Joshua D. and Alan B. Krueger. 1994. "Why Do World War II Veterans Earn More Than Non veterans?", Journal of labor economics, 12 (1), p. 74. Angrist, JD (1990). "Lifetime earnings and the Vietnam era draft lottery: evidence from social security administrative records", American Economic Review, 80 (3), p. 313.

[7] Angrist, Joshua D. 1998. "Estimating the Labor Market Impact of Voluntary Military Service Using Social Security Data on Military Applicants", Econometrica, 66 (2), p. 249.

[8] Angrist, Joshua D. and Stacy C. Chen. 2011. "Schooling and the Vietnam-Era GI Bill: Evidence from the Draft Lottery", American Economic Journal: Applied Economics, 3, p. $96-119$. 
[9] Annan, Jeannie and Christopher Blattman. 2010. "The Consequences of Child Soldiering", Review of Economics and Statistics, 92 (4), p. 882-898.

[10] Banerjee, Abhijit and Lakshmi Iyer. 2010. "History, institutions and economic performance: the legacy of colonial land tenure systems in India", American Economic Review, 95(4): 1190-1213.

[11] BBC News, 2011, "Afghanistan and Pakistan face decisive year", http://news.bbc.co.uk/1/hi/8424289.stm, last accessed 4 January 2011

[12] Bedard, Kelly and Olivier Deschenes. 2006. "The Long-Term Impact of Military Service on Health: Evidence from World War II and Korean War Veterans", American Economic Review, 96(1), p. 176-194.

[13] Benoit, E. 1978. "Growth and Defence in LDCs." Economic Development and Cultural Change, 26, 271-80.

[14] Berger, Mark C., and Barry T. Hirsch. 1983. "The Civilian Earnings Experience of Vietnam-Era Veterans." Journal of Human Resources, 18(4): 455-79.

[15] Bharadwaj, Prashant, Asim Khwaja, and Atif Mian. 2008a. "The partition of India: demographic consequences", Economic and Political Weekly, 39-49 20

[16] Bharadwaj, Prashant, Asim Khwaja, and Atif Mian. 2008b. "The big march: migratory flows after the partition of India", mimeo.

[17] Bodenhorn, Howard, Timothy Guinnane, and Thomas Mroz. 2012. "Caveat Lector: Sample Selection in Historical Heights and the Interpretation of Early Industrializing Economies", NBER Working Paper 19955.

[18] Bound, John, and Sarah Turner. 2002. "Going to War and Going to College: Did World War II and the G.I. Bill Increase Educational Attainment for Returning Veterans?" Journal of Labor Economics, 20(4): 784-815 
[19] Bingley, A. H. 1897. Caste Handbooks for the Indian army: Dogras, Government of India Printing, Simla.

[20] Bingley, A. H. 1899. Caste Handbooks for the Indian army: Sikhs, Government of India Printing, Simla.

[21] Bourne,W. Fitz G. 1914. "Hindustani musalmans and musalmans of the Eastern Punjab," Government of India Printing, Calcutta.

[22] Card, David, and Thomas Lemieux. 2001. "Going to College to Avoid the Draft: The Unintended Legacy of the Vietnam War.", American Economic Review, 91(2): 97-102.

[23] Cassan, Guilhem. 2011. "British law and caste identity manipulation in colonial India: the Punjab Alienation of Land Act.", mimeo FUNDP Namur.

[24] Censor of Indian Mails. 1915. Supplementary Letters forwarded by the Censor, no. $921 / 925$.

[25] Chaudhary, Latika. 2009. "Determinants of Primary Schooling in British India.", The Journal of Economic History, 69, p. 269-302.

[26] Chaudhary, Latika. 2010. "Taxation and Educational Development: Evidence from British India.", Explorations in Economic History, 47, p. 279-293.

[27] Chaudhary, Latika and Jared Rubin. 2010. "Reading, Writing and Religion: Institutions and Human Capital Formation", Journal of Comparative Economics, forthcoming.

[28] Cohen, Stephen P. 1971. The Indian Army - Its Contribution to the Development of a Nation, Universtiy of California Press.

[29] Collier, P. and Hoeffler, A. 2007. Military Spending and the Risk of Coup d'Etats, mimeo, Oxford University. 
[30] Conley, Dalton, and Jennifer A. Heerwig. 2009. "The Long-Term Effects of Military Conscription on Mortality: Estimates from the Vietnam-era Draft Lottery." National Bureau of Economic Research Working Paper 15105.

[31] Conley, Timothy G, Christian B Hansen, and Peter E Rossi. 2012. "Plausibly Exogenous", Review of Economics and Statistics 94 (1): 260-272.

[32] Corrigan, Gondor. 1999. Sepoys in the trenches: the Indian Corps on the Western Front. Howell Press.

[33] Costa, Dora L. and Matthew E. Kahn. 2003. "Cowards and Heroes: Group Loyalty in the American Civil War." 118, Quarterly Journal of Economics, 519-548.

[34] Costa, Dora L. and Matthew E. Kahn. 2007. "Deserters, Social Norms, and Migration.", Journal of Law and Economics, 323-53.

[35] Costa, Dora L., and Matthew E. Kahn. 2008. Heroes and Cowards, Princeton University Press.

[36] Costa, Dora L. and Matthew E. Kahn. 2010. "Health, Wartime Stress, and Unit Cohesion: Evidence from Union Army Veterans", Demography, 47(1), p. 46-66.

[37] Darling, Malcolm. 1930. Rusticus Loquitur or the Old Light and the New in the Punjab Village, Oxford University Press.

[38] Dell, Melissa. 2011. "The Mining Mita: Explaining Institutional Persistence", Econometrica, 78(6).

[39] Duffy, Thomas M. 1985. "Literacy Instruction In the Military." Armed Forces \&5 Society, 11, p. $437-467$.

[40] Duflo, Esther, Pascaline Dupas, and Michael Kremer. 2009. "Additional Resources versus Organizational Changes in Education: Experimental Evidence from Kenya", mimeo JPAL. 
[41] Dunne, J. Paul, Ron P. Smith, and Dirk Willenbockel. 2006. "Models of Military Expenditure and Growth: a Critical Review", Defence and Peace Economics, Vol. 16, (6).

[42] Fafchamps, Marcel and Alex Moradi. 2010. "Referral and Job Performance: Evidence from the Ghana Colonial Army", mimeo, Oxford University and Sussex University.

[43] Falcon. 1892. Caste Handbooks for the Indian army: Sikhs, Government of India Printing, Simla.

[44] Glaeser, Edward L., Rafael LaPorta, Florencio Lopez de Silanes, and Andrei Shleifer. 2004. "Do Institutions Cause Growth?", Journal of Economic Growth, 9, 271-303.

[45] Glewwe, Paul, and Michael Kremer. 2006. "Schools, Teachers, and Education Outcomes in Developing Countries," (with Paul Glewwe), Handbook on the Economics of Education, edited by Erik Hanushek \& F. Welch, Elsevier.

[46] Grenet, J., Hart, R.A., Roberts, E. J. 2011. "Above and Beyond the Call. Long-term Real Earnings Effects of British Male Military Conscription in the Post-war Years", labor Economics, 18(2), p. 194-204.

[47] Grossman, Guy, Devorah Mankin and Dan Miodownik. 2013. "The Political Legacies of Combat: Attitudes Towards War and Peace among Israeli Ex-Combatants", Mimeo.

[48] Huillery, Elise. 2009. "History Matters: The Long-Term Impact of Colonial Public Investments in French West Africa", American economic journal. Applied economics, 1 (2), p. 176.

[49] Humphreys, Macartan, and Jeremy M. Weinstein. 2007. "Demobilization and Reintegration", Journal of Conflict Resolution, 51(4),p. 531-567.

[50] Iyer, Lakshmi 2010. "Direct versus indirect colonial rule in india: Long-term consequences", The Review of Economics and Statistics, Vol. 92, No. 4, Pages 693-713. 
[51] Jha, Saumitra and Steven Wilkinson. 2012. "Veterans and Ethnic Cleansing in the Partition of India", American Political Science Review, forthcoming.

[52] Jones, Kenneth W. 1976. Arya Dharm : Hindu Consciousness in Nineteenth-Century Punjab, Berkeley : University of California Press.

[53] Kaul, Pandit Harikishan. 1912. Report on the Census of Punjab 1911, Government Printing, India

[54] Khalidi, Omar. 2002. "Ethnic Group Recruitment in the Indian Army: The Contrasting Cases of Sikhs, Muslims, Gurkhas and Others", Pacific Affairs, 74 (4), Winter, 20012002, p. 529-552.

[55] Khan, Ahmad Hasan. 1933. Report on the Census of Punjab 1931, Government Printing, India.

[56] Lawrence, James. 1997, Raj - The Making of British India, Abacus, London, p.722.

[57] Lee, Chulhee. 2012. "Military service and Economic Mobility: Evidence from the American civil war", Explorations in Economic History, vol. 49, issue 3, pages 367-379.

[58] Marten, J.T. 1921. Report on the Census of Punjab 1921, Government Printing, India.

[59] Mason, Philip. 1974. A Matter of Honour - an Account of the Indian Army, its Officers and Men, Trinity Press, Worcester and London, p.580.

[60] Mazumder, Rajit K. 2003. The Indian Army and the Making of Punjab, Orient Longman, New Delhi. p.281.

[61] Moradi, Alex. 2008. "Confronting Colonial Legacies - Lessons from Human Development in Ghana and Kenya, 1880-2000", Journal of International Development, 20, p. 11071121. 
[62] Moradi, Alex. 2009. "Towards an Objective Account of Nutrition and Health in Colonial Kenya: A Study of Stature in African Army Recruits and Civilians, 1880-1980", Journal of Economic History, 96(3), 720-755.

[63] Moskos, Charles C. and John Sibley Butler. 1996. All That We Can Be: Black Leadership and Racial Integration the Army Way, N.Y.: Basic Books.

[64] Nurullah, J.P. and Syed Naik. 1951. A history of education in India during the British period. Macmillan.

[65] Pasha, Mustapha Kamal. 1998. Colonial Political Economy: Recruitment and Underdevelopment in the Punjab, Oxford University Press.

[66] Przeworski, Adam. 2007. "Conquered or Granted? A History of Suffrage Extensions", Mimeo, NYU.

[67] Rivas-Rodríguez, Maggie, Emilio Zamora. 2010. Beyond the Latino World War II Hero: The Social and Political Legacy of a Generation, UTexas Press.

[68] Rose, H.A. 1901. Report on the Census of Punjab 1901, Government Printing, India.

[69] Scheve, Ken and David Stasavage. 2010. "The Conscription of Wealth: Mass Warfare and the Demand for Progressive Taxation," International Organization, forthcoming.

[70] Stroup Michael D. and Jac C. Heckelman (2001). "Size of the military sector and economic growth: A panel data analysis of Africa and Latin America", Journal of Applied Economics, 4 (2), p. 329.

[71] Ticchi, Davide and Andrea Vindigni. 2008. "War and endogenous democracy", IZA discussion paper, 3397 .

[72] UNESCO. 2008. International Literacy Statistics: A Review of Concepts, Methodology and Current Data. Montreal: UNESCO Institute for Statistics. 
[73] Wikeley, James Mason. 1915. "Punjabi Musalmans", Government of India Printing, Calcutta.

[74] World Bank Development Indicators, 2006. 


\section{Online Appendix}

\section{A.1 Map and figures}

Figure 4: War deaths in colonial Punjab

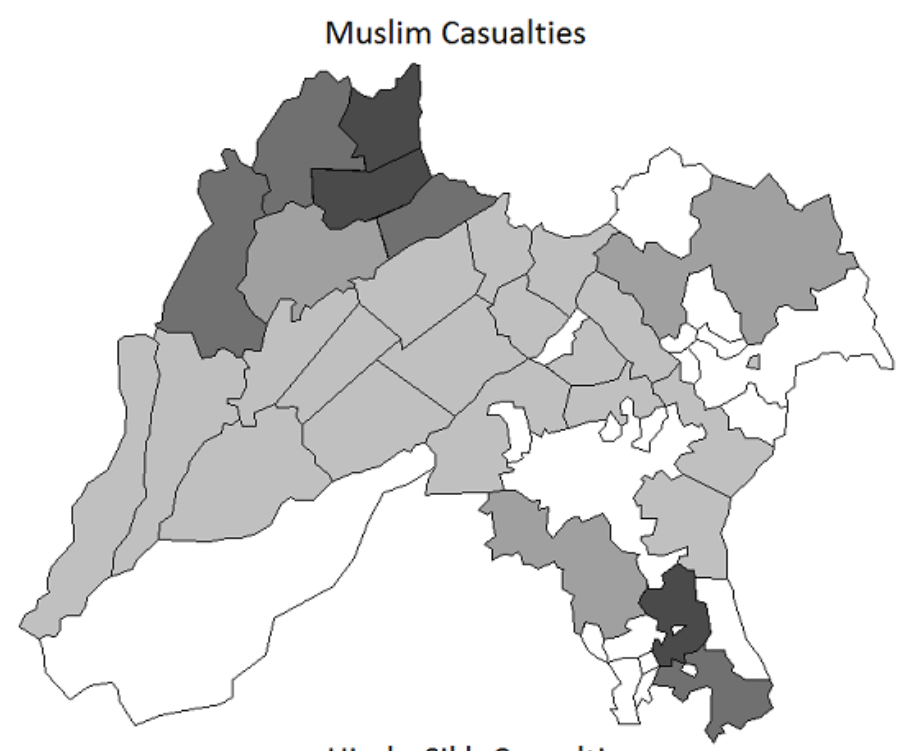

Hindu-Sikh Casualties

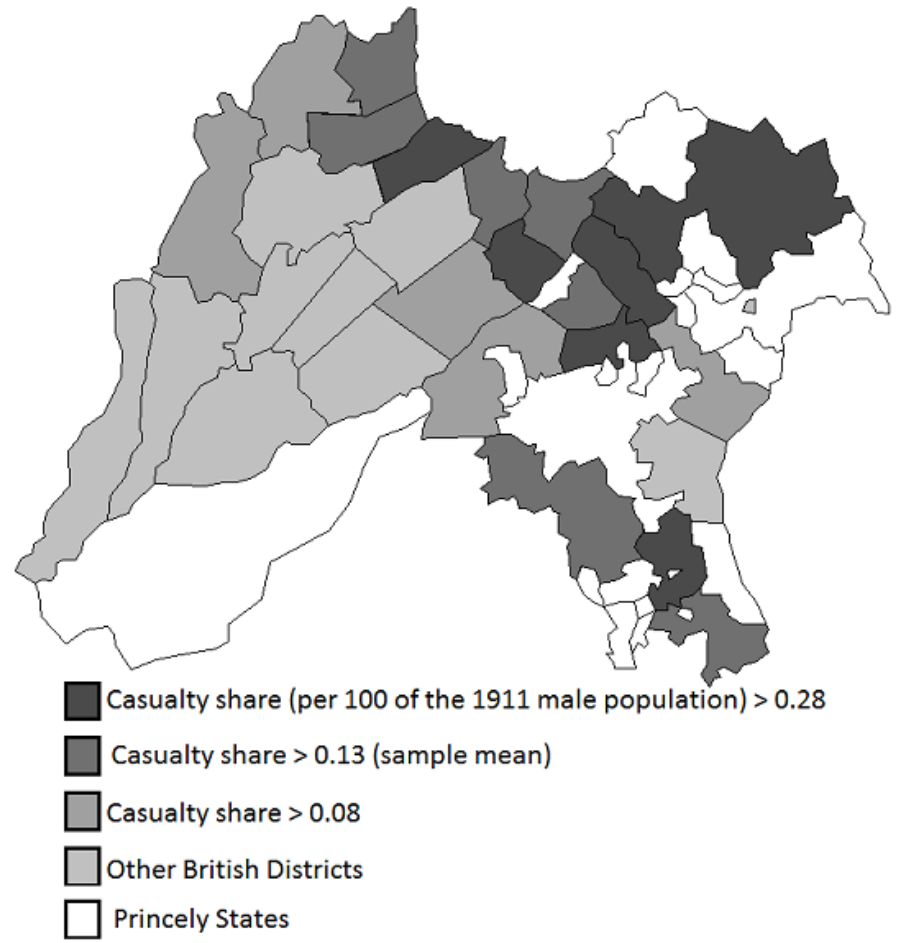


Figure 5: Casualty rates per battlefront

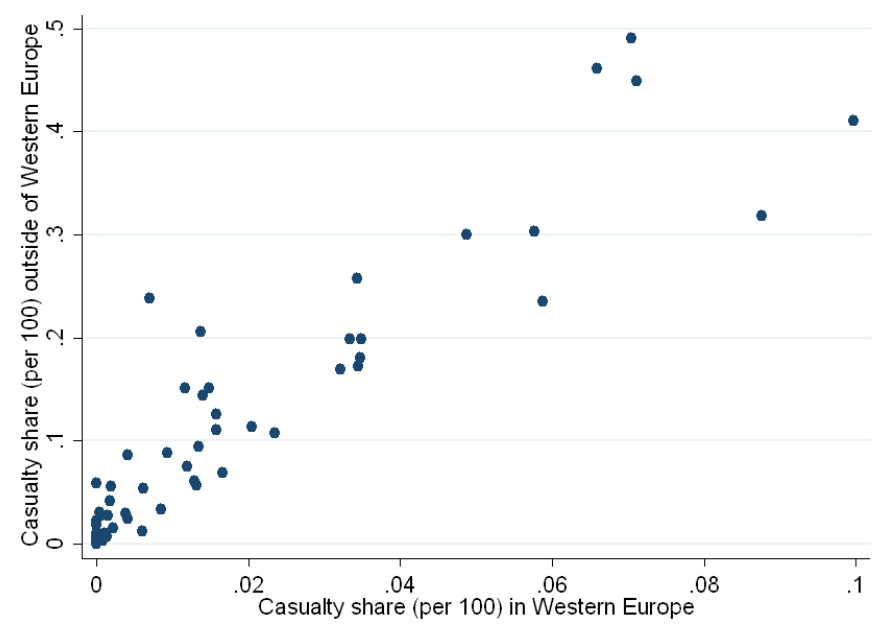

Figure 6: Casualty rates per casualty profile

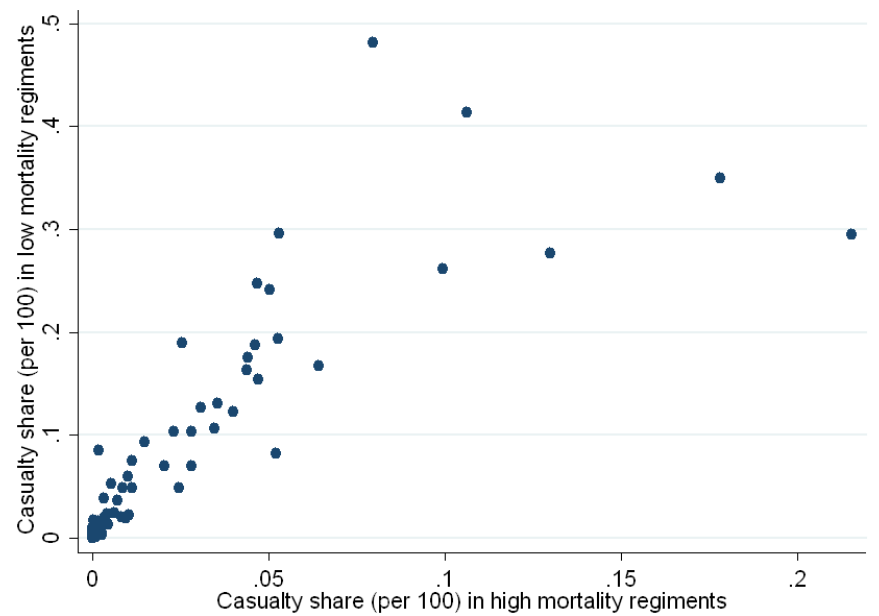

Figure 7: Higher ranks versus soldier ranks

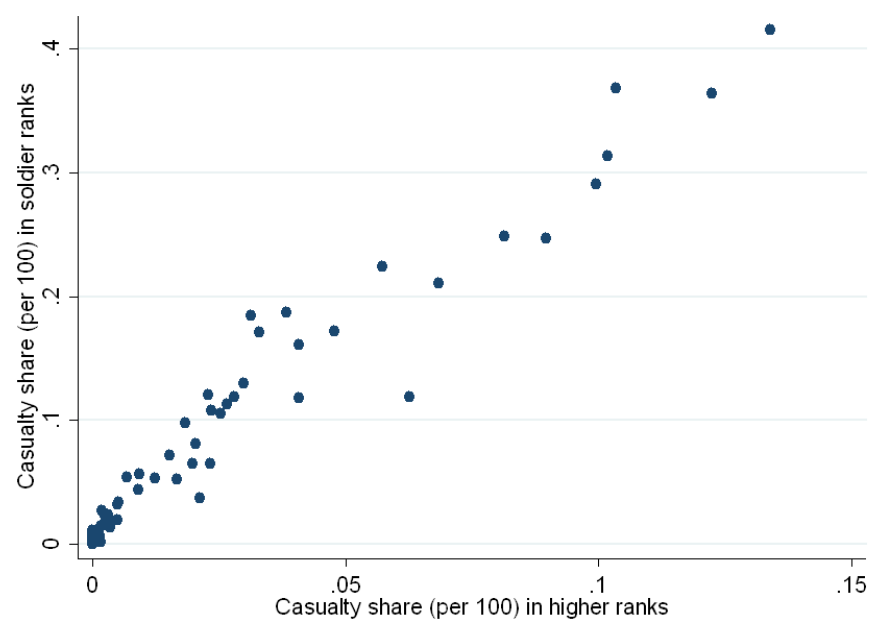

Notes: District-religion level observations, for 56 groups (Hindu-Sikh and Muslim, in 28 districts). Casualty shares are expressed per 100 of the 1911 male population. "High mortality regiments" (figure 6) are in the top $10 \%$ of the regiment-level distribution of the total number of casualties. Soldier ranks (figure 7) include gunners, riflemen, sorwars, and sepoys. 


\section{A.2 Punjab's policy environment}

In his detailed historical account, Mazumder (2003) provides descriptive evidence on a wide range of policies that were related to Punjab's status as a military recruitment ground. A first policy directly targeted recruited soldiers. Soldiers were among the main beneficiaries of land grants in the so-called canal colonies. These colonies contained newly created tracts of cultivable land irrigated by canals. The primary aim of these projects was to generate more revenue by developing potentially fertile areas and moving some of the population away from densely populated regions to the newly established colonies (Mazumder, 2003, p.66). ${ }^{49}$ Even though most canalization projects were completed before the war, Mazumder notes that soldiers were given preference in the allocation of new tracts of land after WWI. This policy is unlikely to lead to an upward bias of our estimates, as ex-soldiers who moved to the colonies would dampen the extent to which recruited communities would have benefited from improvements in literacy. A second policy that directly benefited recruited districts was taxation after the war. The main source of income of the Raj came in the form of taxes on agriculture. These taxes were laid down in so-called revenue assessments. Descriptive evidence suggests that, mainly after WWI, heavily recruited districts enjoyed more favorable assessments. This policy is unlikely to drive the results, because it was only implemented after the war and there is evidence of a positive impact from 1921 onwards. However, this channel may have caused spill-overs of military service on household incomes in the home communities. A third policy that may have affected recruited communities is the Punjab Land Alienation Act (1901), which protected agricultural castes (among whom mainly martial races) from indebtedness by outlawing land sales from agricultural to non-agricultural castes. ${ }^{50}$ While the families of recruited soldiers could have benefited from the Land Alienation Act, the Act applied to a wider set of agricultural castes in the whole of Punjab and not just to those that delivered recruits. Also, the Act was implemented well before First

\footnotetext{
${ }^{49}$ By 1931, Punjab had 9,929,219 acres of land irrigated by government canals, which corresponds to $46 \%$ of land irrigated by canals in the whole of British India.

${ }^{50}$ See Cassan (2011) for a detailed description of the Punjab Land Alienation Act and the incentives it created to manipulate caste identity.
} 
World War. Therefore, it is unlikely that the main results are merely capturing the different literacy trends of those communities that benefited the most from the Land Alienation Act. In conclusion, the measures discussed in this section should not confound the main results because of their timing and their geographical application. However, the military importance of Colonial Punjab created an environment that could have strengthened the impact of military recruitment. Therefore, these factors could be relevant for the extrapolation of Punjab's experience to other contexts of large scale voluntary military service. 


\title{
A.3 Further robustness checks
}

\author{
A.3.1 Robustness to border changes
}

Table 11: Baseline specification for merged districts

\begin{tabular}{|c|c|c|c|c|c|c|}
\hline & \multicolumn{2}{|c|}{$\begin{array}{c}\log (\text { male literacy } \\
\text { rate })\end{array}$} & \multicolumn{2}{|c|}{ Log(male literates) } & \multicolumn{2}{|c|}{$\begin{array}{c}\log (\text { male } \\
\text { population) }\end{array}$} \\
\hline & $\begin{array}{l}\text { Over } 20 \\
(1)\end{array}$ & $\begin{array}{c}\text { Under } 20 \\
(2)\end{array}$ & $\begin{array}{c}\text { Over } 20 \\
(3)\end{array}$ & $\begin{array}{c}\text { Under } 20 \\
(4)\end{array}$ & $\begin{array}{c}\text { Over } 20 \\
(5)\end{array}$ & $\begin{array}{c}\text { Under } 20 \\
(6)\end{array}$ \\
\hline $\begin{array}{l}\text { Casualty rate } \\
{ }^{*} 1921\end{array}$ & $\begin{array}{c}0.60^{* * *} \\
(0.22)\end{array}$ & $\begin{array}{c}0.38 \\
(0.35)\end{array}$ & $\begin{array}{c}0.45^{* *} \\
(0.19)\end{array}$ & $\begin{array}{c}0.22 \\
(0.35)\end{array}$ & $\begin{array}{l}-0.15 \\
(0.13)\end{array}$ & $\begin{array}{l}-0.16^{*} \\
(0.09)\end{array}$ \\
\hline $\begin{array}{l}\text { Casualty rate } \\
*_{1} 1931\end{array}$ & $\begin{array}{c}0.91^{* * *} \\
(0.31)\end{array}$ & $\begin{array}{c}1.07^{* * *} \\
(0.37)\end{array}$ & $\begin{array}{c}0.87^{* * *} \\
(0.36)\end{array}$ & $\begin{array}{c}0.90^{* * *} \\
(0.39)\end{array}$ & $\begin{array}{l}-0.04 \\
(0.26)\end{array}$ & $\begin{array}{l}-0.18 \\
(0.25)\end{array}$ \\
\hline Observations & 96 & 96 & 96 & 96 & 96 & 96 \\
\hline \multicolumn{7}{|c|}{$\begin{array}{l}\text { Notes: District-religion level observations for } 32 \text { groups (Muslim or Hindu-Sikh, in } 16 \text { merged } \\
\text { districts), for three census years }(1911-31) \text {. Standard errors are clustered at the } \\
\text { district-religion level. }{ }^{* * *} \mathrm{p}<0.01,{ }^{* *} \mathrm{p}<0.05,{ }^{*} \mathrm{p}<0.1 \text {. }\end{array}$} \\
\hline
\end{tabular}

The districts analyzed in this paper were subject to several border changes of the period under consideration. While most of these border changes were small and are not expected to affect the literacy rate systematically, this section explores the robustness of the main findings to accounting more explicitly for border changes. In table 11 , I conduct the analysis at the level of merged British districts with stable borders. The Princely States were not affected by these border changes and are not included in this robustness check. The main results carry through, but there is some evidence in these adjusted samples of negative impacts of military recruitment on the size of the population. To address the concern that the impacts on literacy are reflecting changes in the composition of the population, the main results are also shown for the logarithm of the number of male literates rather than the corresponding literacy rates in columns (3) and (4). 


\section{A.3.2 District-level clusters}

Table 12: Baseline specification (district clusters)

\begin{tabular}{|c|c|c|c|c|c|c|}
\hline & \multicolumn{3}{|c|}{ Log(male literacy rate) } & \multicolumn{3}{|c|}{ Log(male population) } \\
\hline & $\begin{array}{c}\text { All ages } \\
\text { (1) }\end{array}$ & $\begin{array}{c}\text { Over } 20 \\
(2)\end{array}$ & $\begin{array}{c}\text { Under } 20 \\
(3)\end{array}$ & $\begin{array}{c}\text { All ages } \\
(4)\end{array}$ & $\begin{array}{c}\text { Over } 20 \\
(5)\end{array}$ & $\begin{array}{c}\text { Under } 20 \\
(6)\end{array}$ \\
\hline $\begin{array}{l}\text { Casualty rate } \\
* 1921\end{array}$ & $\begin{array}{c}0.33^{* *} \\
(0.16) \\
{[0.17]}\end{array}$ & $\begin{array}{c}0.40^{* *} \\
(0.15) \\
{[0.16]}\end{array}$ & $\begin{array}{c}0.06 \\
(0.21) \\
{[0.21]}\end{array}$ & $\begin{array}{c}0.13 \\
(0.17) \\
{[0.21]}\end{array}$ & $\begin{array}{c}0.13 \\
(0.17) \\
{[0.22]}\end{array}$ & $\begin{array}{c}0.14 \\
(0.17) \\
{[0.21]}\end{array}$ \\
\hline $\begin{array}{l}\text { Casualty rate } \\
* 1931\end{array}$ & $\begin{array}{c}0.47^{*} \\
(0.24) \\
{[0.26]}\end{array}$ & $\begin{array}{c}0.50^{* *} \\
(0.20) \\
{[0.22]}\end{array}$ & $\begin{array}{c}0.30 \\
(0.33) \\
{[0.35]}\end{array}$ & $\begin{array}{c}0.10 \\
(0.19) \\
{[0.24]}\end{array}$ & $\begin{array}{c}0.10 \\
(0.19) \\
{[0.18]}\end{array}$ & $\begin{array}{c}0.09 \\
(0.20) \\
{[0.25]}\end{array}$ \\
\hline Observations & 168 & 168 & 168 & 168 & 168 & 168 \\
\hline \multicolumn{7}{|c|}{$\begin{array}{l}\text { Notes: District-religion level observations for } 56 \text { groups (Muslim or Hindu-Sikh, in } 28 \\
\text { districts), for three census years (1911-31). Casualty rates are expressed per } 100 \text { of the } 1911 \\
\text { male population. All regressions include district-religion fixed effects and religion-year effects. } \\
\text { (s.e.) are clustered at the district-religion level, [s.e.] at the district level. } * * * p<0.01,{ }^{* *} \\
\mathrm{p}<0.05, * \mathrm{p}<0.1 \text {. }\end{array}$} \\
\hline
\end{tabular}

The main results at the district-religion level used clustered standard errors at the districtreligion level, because this is the level at which the recruitment variable varies. However, standard errors that are clustered at the district level remain almost identical to the unclustered errors (although the limited number of districts could affect the consistency of these estimates). 


\section{A.3.3 Rank Analysis}

\section{Table 13: Baseline specification for soldier rank casualties}

\begin{tabular}{lccc}
\hline \hline & & \multicolumn{2}{c}{$\log ($ male literacy rate) } \\
& $\begin{array}{c}\text { All ages } \\
(1)\end{array}$ & Over 20 & Under 20 \\
& 42.49 & $50.52^{*}$ & 10.68 \\
Casualty rate & $(26.96)$ & $(27.43)$ & $(30.30)$ \\
$* 1921$ & $70.27^{*}$ & $68.05^{* *}$ & 61.01 \\
Casualty rate & $(36.21)$ & $(31.22)$ & $(49.83)$ \\
$*$ 19231 & 168 & 168 & 168 \\
Observations & Notes: District-religion level observations for 56 groups (Muslim or Hindu-Sikh, in 28 \\
districts), for three census years (1911-31). All regressions include district-religion fixed effects \\
and religion-year effects. Standard errors are clustered at the district-religion level. *** \\
$\mathrm{p}<0.01, * * \mathrm{p}<0.05, * \mathrm{p}<0.1$.
\end{tabular}

In the empirical strategy (section 5), it was argued that literate soldiers should not have faced a different casualty pattern than illiterate soldiers. In further support of this hypothesis, I can distinguish between casualties from three categories of army ranks: soldiers, above-soldier ranks and military personnel in supportive roles. The comparison I make is between soldiers (Sepoy, Riflemen, or Sowar) and "all higher ranks". The vast majority of these "higher ranks" are at the NCO level: corporal (Naik, Lance Daffaldar) and Sergeant (Havildar or Daffadar). The highest level an Indian soldier could aspire to was Subadar Major, which is junior to the most junior british Second Lieutenant (Corrigan, 1999, p.11).

An alternative explanation of the key results could have been that higher ranks were driving this impact. This could be the case if higher ranks were recruited from regions with a higher potential for literacy improvement and if they had different casualty patterns (at the district-religion level) than the lower ranks. Under the latter scenario, the proxy approach would lead to an upward bias of the impact of military recruitment. The similarity of the recruitment patterns suggests that this is an unlikely scenario: table 13 confirms that the 
key results are unchanged if casualty rates are calculated using only soldier ranks (excluding higher ranks and other groups). 


\section{A.3.4 Timing of casualties}

Table 14: Baseline specification for casualties before 1916

\begin{tabular}{|c|c|c|c|}
\hline & \multicolumn{3}{|c|}{ Log(male literacy rate) } \\
\hline & $\begin{array}{c}\text { All ages } \\
(1)\end{array}$ & $\begin{array}{c}\text { Over } 20 \\
(2)\end{array}$ & $\begin{array}{c}\text { Under } 20 \\
(3)\end{array}$ \\
\hline $\begin{array}{l}\text { Casualty rate } \\
\text { (before 1916) } \\
\text { *1921 }\end{array}$ & $\begin{array}{l}1.08^{*} \\
(0.60)\end{array}$ & $\begin{array}{c}1.26^{* *} \\
(0.58)\end{array}$ & $\begin{array}{c}0.33 \\
(0.73)\end{array}$ \\
\hline $\begin{array}{l}\text { Casualty rate } \\
\text { (before 1916) } \\
\text { *1931 }\end{array}$ & $\begin{array}{l}1.79^{*} \\
(0.95)\end{array}$ & $\begin{array}{c}1.85^{* *} \\
(0.80)\end{array}$ & $\begin{array}{c}1.31 \\
(1.32)\end{array}$ \\
\hline Observations & 168 & 168 & 168 \\
\hline \multicolumn{4}{|c|}{$\begin{array}{l}\text { Notes: District-religion level observations for } 56 \text { groups (Muslim or Hindu-Sikh, in } 28 \\
\text { districts), for three census years }(1911-31 \text { ). The casualty rate is calculated as the number of } \\
\text { deaths before } 1916 \text {, divided by the } 1911 \text { male population. All regressions include } \\
\text { district-religion fixed effects and religion-year effects. Standard errors are clustered at the } \\
\text { district-religion level. } * * * p<0.01, * * p<0.05, * p<0.1 \text {. }\end{array}$} \\
\hline
\end{tabular}

As shown earlier in figure 3, the casualty patterns are very similar before and after 1916. Table 14 confirms that the key results go through if only casualties from the early stages of the First World War (1914 and 1915) are included. As a result, war-time specific recruitment practices are unlikely to bias the main findings. 


\title{
A.3.5 Cohort Analysis
}

\section{Table 15: Baseline specification for cohort changes}

\author{
$\log \left(\right.$ male literacy rate over $20 /$ male literacy rate $_{t-1} 10$ to 20$)$
}

\section{(1)}

\begin{tabular}{lc} 
Casualty rate & $0.49^{* * *}$ \\
$* 1921$ & $(0.17)$ \\
District FE & $\mathrm{Y}$ \\
Religion & \\
dummy & $\mathrm{Y}$ \\
Observations & 56 \\
\hline
\end{tabular}

Notes: District-religion level observations for 56 groups (Muslim or Hindu-Sikh, in 28

districts), in 1921. Standard errors are clustered at the district-religion level. ${ }^{* * *} \mathrm{p}<0.01,{ }^{* *}$ $\mathrm{p}<0.05, * \mathrm{p}<0.1$.

It was argued in section 6 that the results are most consistent with the direct acquisition of literacy skills by serving soldiers. Under this hypothesis, we should observe that the cohort that served in the war gained additional literacy skills during the war. It should be noticed that the earlier analysis did not correspond to a cohort analysis, as I compared the same age groups at different points in time (which allows the composition of these groups to change). The split up of literacy rates provided in the census does not allow for a detailed cohort analysis in different age categories. However, I can construct a variable that approximates the literacy changes for the cohorts of 10-to-20-year-olds in 1901, 1911 and 1921:

$$
y_{r, d, t}=\log \left(\text { literacy } y_{r, d, t}^{o v e r 20}\right)-\log \left(\text { literac } y_{r, d, t-1}^{10 t o 20}\right)
$$

This variable does not correspond to the actual cohort-specific change in literacy rates, as I need to use the broader category of over-20- year-olds. Table 15 confirms that the main results are confirmed in a cohort analysis. District dummies are included to account for any determinants of the cohort literacy gains that are district-specific. 


\section{A.3.6 District-year fixed effects}

\section{Table 16: Baseline results with district-year effects}

\begin{tabular}{|c|c|c|c|c|c|c|}
\hline & \multicolumn{3}{|c|}{$\log ($ male literacy rate) } & \multicolumn{3}{|c|}{ Log(male population) } \\
\hline & $\begin{array}{c}\text { All ages } \\
(1)\end{array}$ & $\begin{array}{c}\text { Over } 20 \\
(2)\end{array}$ & $\begin{array}{c}\text { Under } 20 \\
(3)\end{array}$ & $\begin{array}{c}\text { All ages } \\
(4)\end{array}$ & $\begin{array}{c}\text { Over } 20 \\
(5)\end{array}$ & $\begin{array}{c}\text { Under } 20 \\
(6) \\
\end{array}$ \\
\hline $\begin{array}{l}\text { Casualty share } \\
\text { *1921 }\end{array}$ & $\begin{array}{l}0.26^{*} \\
(0.15)\end{array}$ & $\begin{array}{l}0.26^{*} \\
(0.14)\end{array}$ & $\begin{array}{c}0.21 \\
(0.21)\end{array}$ & $\begin{array}{l}-0.04 \\
(0.07)\end{array}$ & $\begin{array}{l}-0.02 \\
(0.09)\end{array}$ & $\begin{array}{l}-0.06 \\
(0.05)\end{array}$ \\
\hline $\begin{array}{l}\text { Casualty share } \\
* 1931\end{array}$ & $\begin{array}{c}0.73^{* * *} \\
(0.24)\end{array}$ & $\begin{array}{c}0.60^{* * *} \\
(0.22)\end{array}$ & $\begin{array}{c}0.94^{* * *} \\
(0.32)\end{array}$ & $\begin{array}{l}-0.12 \\
(0.12)\end{array}$ & $\begin{array}{c}0.01 \\
(0.11)\end{array}$ & $\begin{array}{c}-0.26^{* *} \\
(0.13)\end{array}$ \\
\hline District-year effects & Yes & Yes & Yes & Yes & Yes & Yes \\
\hline Observations & 168 & 168 & 168 & 168 & 168 & 168 \\
\hline \multicolumn{7}{|c|}{$\begin{array}{l}\text { Notes: Observations are at the district-religion level for } 56 \text { groups (Hindu-Sikh and Muslim, in } \\
28 \text { districts) and for three census years (1911-31). All regressions include district-religion fixed } \\
\text { effects. Standard errors are clustered at the district-religion level. }{ }^{* * *} \mathrm{p}<0.01,{ }^{* *} \mathrm{p}<0.05 \text {, * } \\
\mathrm{p}<0.1 \text {. }\end{array}$} \\
\hline
\end{tabular}

One way to check if any policy that affected districts rather than religious communities can explain the observed pattern in literacy rates is to include district-year effects in the main regression. These effects fully absorb the impact of all district-level variables that affected both communities to the same extent. The availability of transport and trade infrastructure could be one example of an omitted variable that mainly operates at the district level. ${ }^{51}$ In my small sample, a lot of variation is lost in this approach, as districts with similar recruitment intensities for both religions are no longer used to identify the main effect. In a regression of casualty rates on religion dummies, the $\mathrm{R}^{2}$ jumps from $3 \%$ to $70 \%$ when district dummies are included. Nevertheless, the results presented in Table 16 are broadly consistent with earlier findings. One difference is that the coefficient on the casualty ratio in 1931 gains significance for under-20-year-olds. This result suggests that inter-generational spill-

\footnotetext{
${ }^{51}$ Due to its geographical closeness to the North West Frontier (which was of major military importance), Punjab received significant investments in its transport infrastructure. These investments were not restricted to recruited communities nor did they target these communities in particular: by 1911, all but two districts were connected to the railroad network (Marten, 1911).
} 
overs could previously have been obscured by variables affecting literacy at the district level. However, the size of the population of under-20-years-old decreases significantly in column (6), which implies that the observed increase in the literacy rate for under-20-year-olds could partly reflect a decrease in the denominator. 


\section{A.3.7 Heterogeneity}

\section{Table 17: Religious heterogeneity}

\begin{tabular}{|c|c|c|c|}
\hline \multicolumn{4}{|c|}{$\log ($ male literacy $)$} \\
\hline & $\begin{array}{c}\text { All ages } \\
\text { (1) }\end{array}$ & $\begin{array}{c}\text { Over } 20 \\
(2)\end{array}$ & $\begin{array}{c}\text { Under } 20 \\
(3)\end{array}$ \\
\hline $\begin{array}{l}\text { Casualty rate } \\
\text { *1921 }\end{array}$ & $\begin{array}{c}0.35 \\
(0.30)\end{array}$ & $\begin{array}{c}0.38 \\
(0.31)\end{array}$ & $\begin{array}{c}0.11 \\
(0.31)\end{array}$ \\
\hline $\begin{array}{l}\text { Casualty rate } \\
\text { *1931 }^{*}\end{array}$ & $\begin{array}{c}0.59 \\
(0.36)\end{array}$ & $\begin{array}{l}0.58^{*} \\
(0.33)\end{array}$ & $\begin{array}{c}0.48 \\
(0.46)\end{array}$ \\
\hline $\begin{array}{l}\text { Casualty rate } \\
\text { *Muslim*1921 }\end{array}$ & $\begin{array}{l}-0.18 \\
(0.35)\end{array}$ & $\begin{array}{l}-0.14 \\
(0.35)\end{array}$ & $\begin{array}{l}-0.12 \\
(0.43)\end{array}$ \\
\hline $\begin{array}{l}\text { Casualty rate } \\
* \text { Muslim*1931 }\end{array}$ & $\begin{array}{l}-0.21 \\
(0.43)\end{array}$ & $\begin{array}{l}-0.20 \\
(0.37)\end{array}$ & $\begin{array}{l}-0.15 \\
(0.60)\end{array}$ \\
\hline Observations & 249 & 249 & 249 \\
\hline \multicolumn{4}{|c|}{$\begin{array}{l}\text { Notes: District-religion level observations for } 56 \text { groups (Muslim or Hindu-Sikh, in } 28 \\
\text { districts) and for three census years (1911-31). All regressions include district-religion } \\
\text { fixed effects, religion-year effects, colony-year effects, and princely-state-year effects. } \\
\text { Standard errors are clustered at the district-religion level. }{ }^{* * *} \mathrm{p}<0.01,{ }^{* *} \mathrm{p}<0.05,{ }^{*} \\
\mathrm{p}<0.1 \text {. }\end{array}$} \\
\hline
\end{tabular}

Given the data availability constraints, the district-religion level is the finest level at which the analysis can be conducted. This approach also enables a comparison between the treatment effects of Muslims and Hindu-Sikhs respectively. ${ }^{52}$ The results presented in table 17 suggest that the impact is largest for Hindu-Sikhs, but the difference between the treatment effects is not statistically significant and, for over-20-year-olds, the effect remains positive and large for Muslims.

\footnotetext{
${ }^{52}$ Chaudhary and Rubin (2010) highlight the importance of the proportion of Muslims in the district to explain Muslim literacy levels in 1911 and 1921. The Punjabi districts under consideration all have a Muslim population that is larger than $28 \%$ of the population and the level effect of the share of Muslims reported by Chaudhary and Rubin should be captured by the district(-religion) fixed effects in my approach.
} 


\section{A.3.8 Log-log scale}

As figure 3 contains many observations close to zero, the following figure represents the same data on a log-log scale. The correlation between the two casualty measures remains very strong. The larger variation at low casualty rates reflects larger proportional differences, but it should be kept in mind that the underlying casualty rates are very close to zero. The main specification is based on absolute differences in casualty rates, i.e. the variation shown in 3 of the main text.

Figure 8: Time pattern of casualty shares at the district-religion level

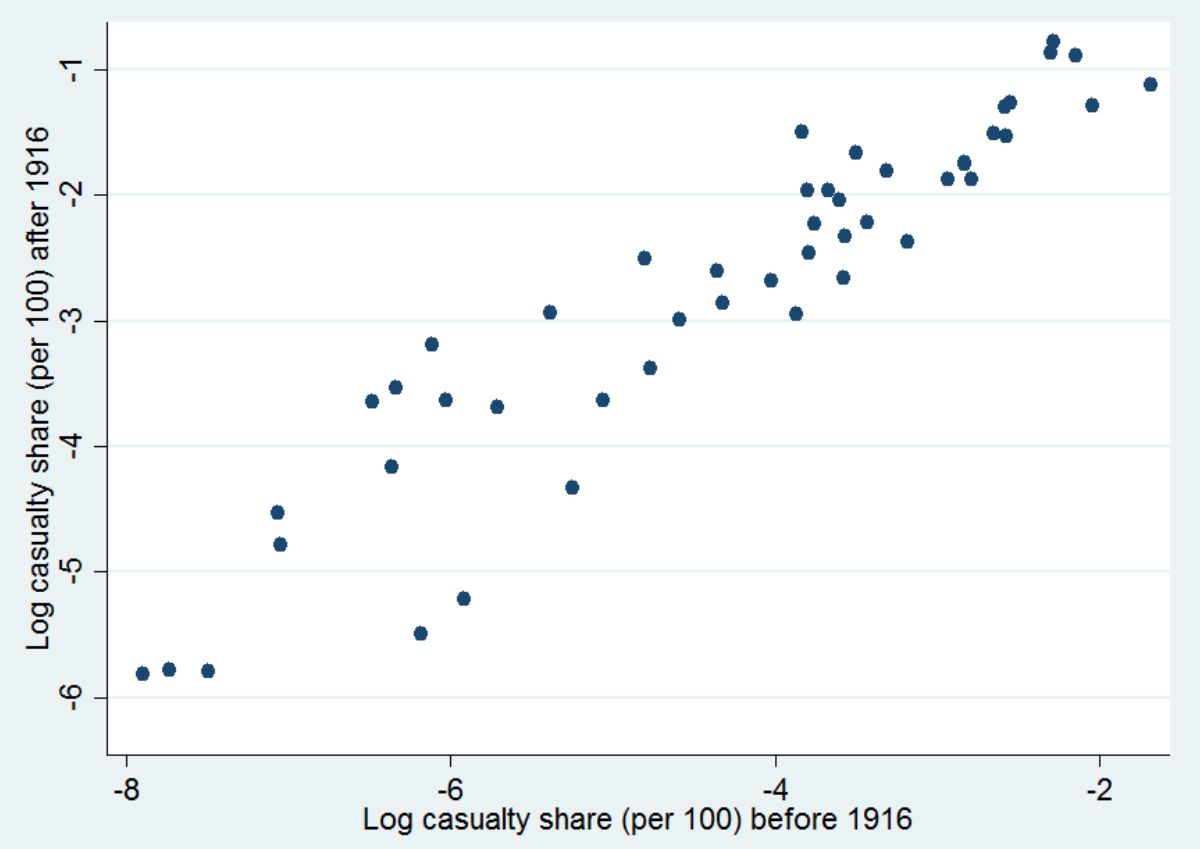

Notes: Observations are at the district-religion level, for 56 groups (Hindu-Sikh and Muslim, in 28 districts). Casualty shares are expressed per 100 of the 1911 male population. 


\section{A.3.9 Further IV results}

\section{A.3.9.1 Complete IV-OLS comparison}

Figure 18 provides a full comparison of IV and OLS results.

\section{A.3.9.2 Sensitivity analysis}

While the exogeneity of the instrument is cannot be proven, Conley, Hansen and Rossi (2012) developed a method to assess the sensitivity of IV estimates to violations of the exclusion restriction. Figure 9 shows the effect of military recruitment on the male literacy rate, allowing for a direct impact of recruitment suitability measure that is uniformly distributed between zero and $\delta$. As long as delta remains smaller than 0.4, the effect remains significant at $10 \%$ for all age groups. For the male literacy rate of over 20 year-olds, the effect remains significant for $\delta$ smaller than 0.9 . As the reduced form effect of the recruitment suitability measure on literacy in 1931 is 0.21 , the IV results are robust to substantial deviations from perfect exogeneity. The graphs also indicate that, in spite of large confidence intervals (even under the assumption of perfect exogeneity), the coefficient remains quite stable as the model moves away from perfect exogeneity. 


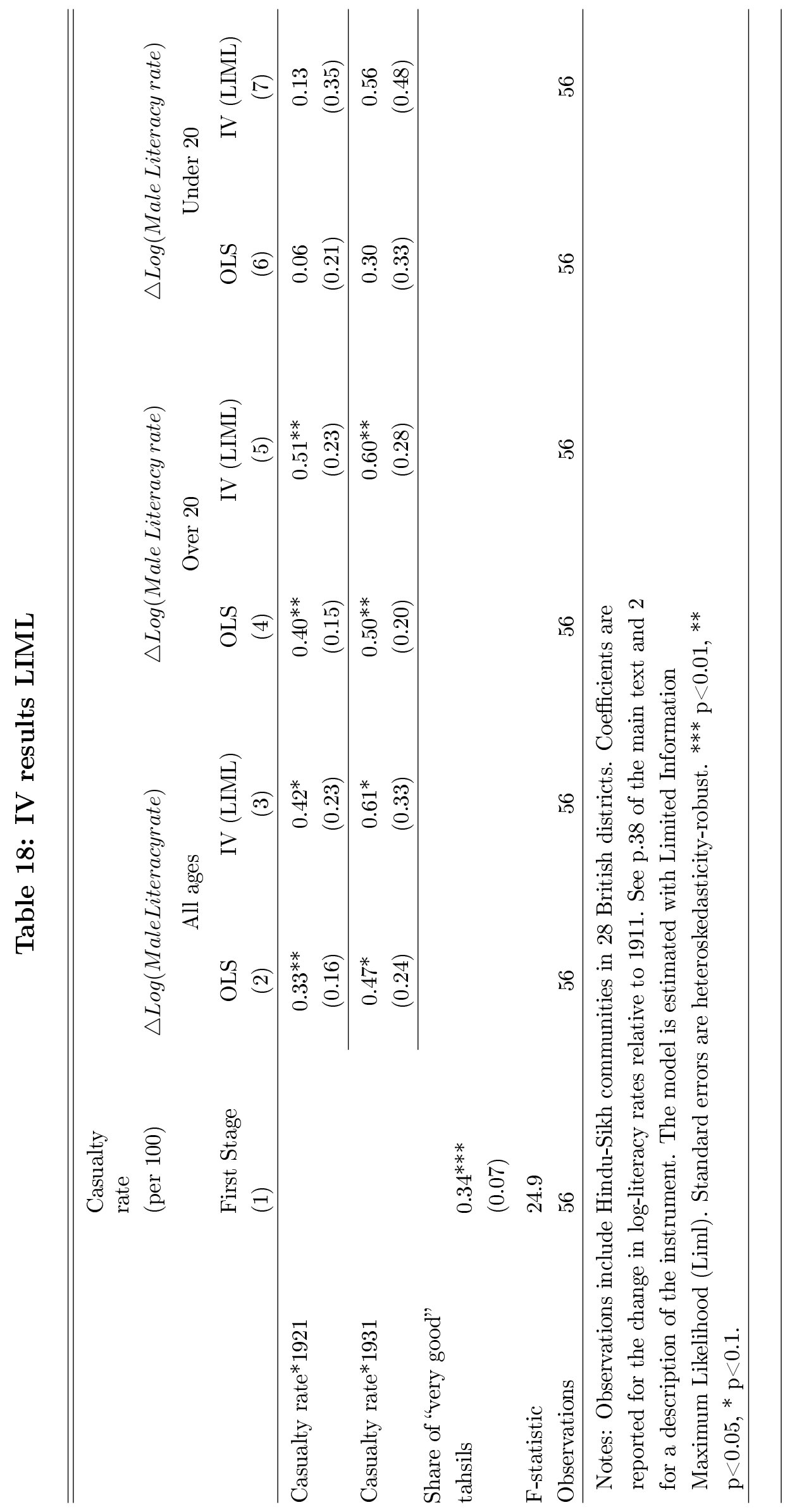


Figure 9: Sensitivity of IV results to the exclusion restriction: all ages

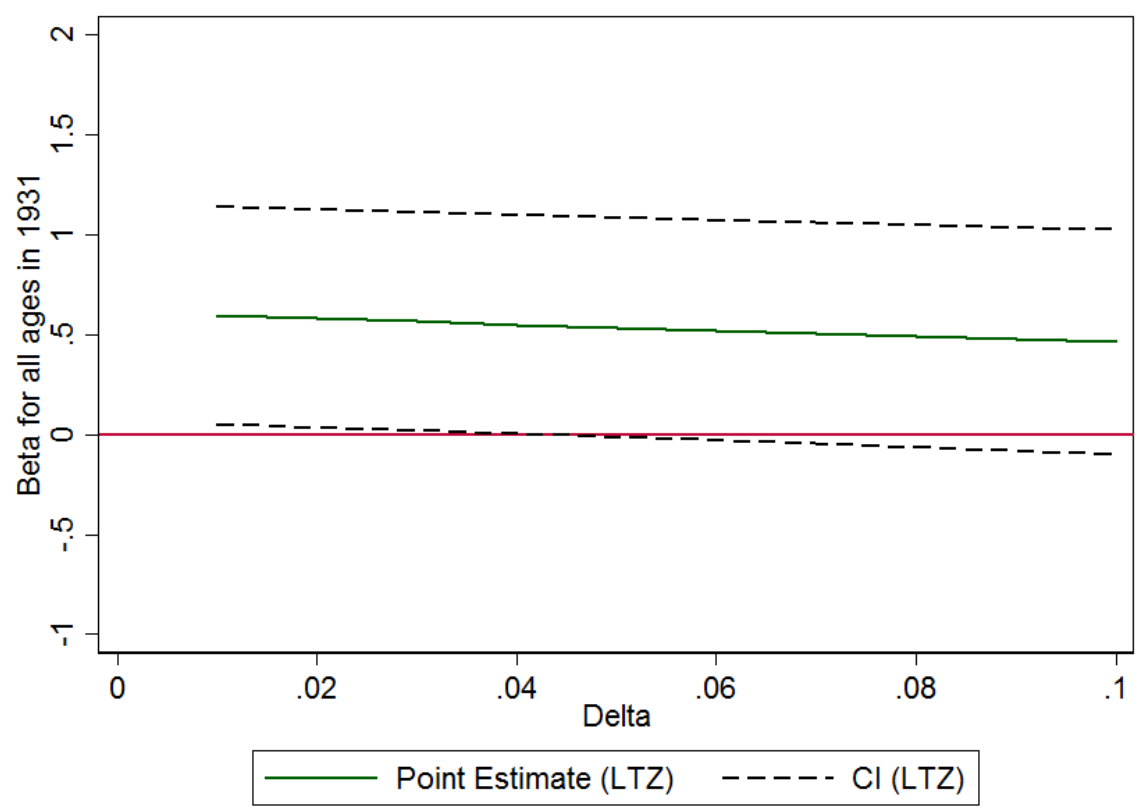

Figure 10: Sensitivity of IV results to the exclusion restriction: over 20 year olds

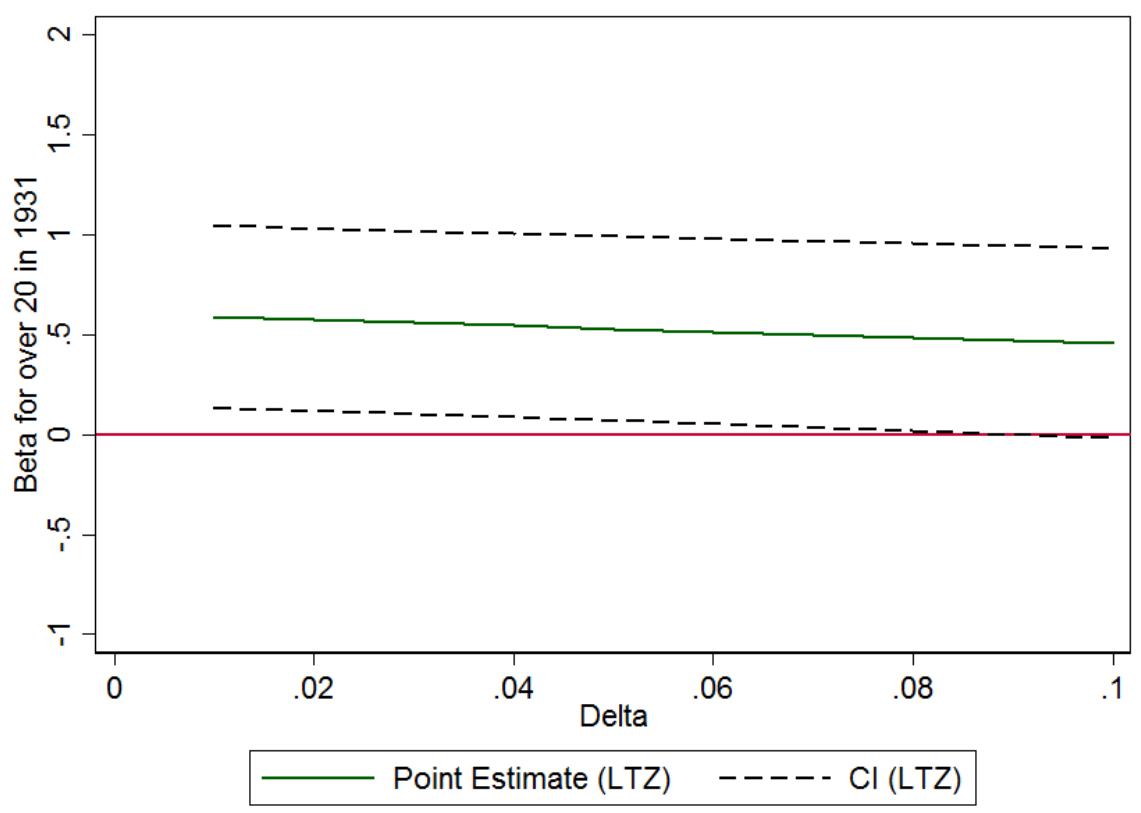

Notes: Local-to-zero estimates and $90 \%$ confidence intervals for the 1931 IV coefficient in table 7 , following Conley, Hansen, and Rossi (2012). The direct effect of recruitment suitability ( $\gamma$ in Conley et al,, 2012) is uniformly distributed between zero and $\delta$. The reduced form coefficient on the instrument is 0.21 . 


\section{A.3.10 Comparison with Princely States}

In table 19, I include the Princely States in the sample. I restrict the analysis to those communities with at least 4,000 male individuals in 1911, which makes sure that the Princely State communities are at least comparable to the smallest community in a British District (the results are robust to changing this threshold). The results show that military casualties did not affect literacy rates significantly differently in the princely states. In line with the very heterogeneous characteristics of the Princely states, the separate effects in Princely States are very imprecisely estimated. Still, the insignificance of the differences and the small magnitude of the difference in 1921 are consistent with the idea that public policies (including educational investments) in the British districts are not driving the observed literacy gains. Nevertheless, it should be pointed out that (in terms of magnitude) the impact of war casualties in the Princely States disappears in 1931.

\section{Table 19: Princely States vs. British Districts}

\begin{tabular}{|c|c|c|c|c|c|c|}
\hline \multirow{4}{*}{$\begin{array}{l}\text { Casualty rate } \\
* 1921\end{array}$} & \multicolumn{6}{|c|}{$\log ($ male literacy rate) } \\
\hline & \multicolumn{2}{|c|}{ All ages } & \multicolumn{2}{|c|}{ Over 20} & \multicolumn{2}{|c|}{ Under 20} \\
\hline & 0.23 & 0.24 & $0.28^{*}$ & $0.29^{*}$ & -0.02 & -0.03 \\
\hline & $(0.16)$ & $(0.17)$ & $(0.17)$ & $(0.17)$ & $(0.20)$ & $(0.20)$ \\
\hline \multirow{2}{*}{$\begin{array}{l}\text { Casualty rate } \\
{ }^{*} 1931\end{array}$} & 0.34 & $0.39^{*}$ & $0.35^{*}$ & $0.39 * *$ & 0.14 & 0.17 \\
\hline & $(0.21)$ & $(0.21)$ & $(0.18)$ & $(0.18)$ & $(0.28)$ & $(0.29)$ \\
\hline \multirow{2}{*}{$\begin{array}{l}\text { Casualty rate } \\
* 1921 * \text { Princely }\end{array}$} & & -0.11 & & -0.07 & & 0.05 \\
\hline & & $(0.34)$ & & $(0.36)$ & & $(0.38)$ \\
\hline \multirow{2}{*}{$\begin{array}{l}\text { Casualty rate } \\
* 1931 * \text { Princely }\end{array}$} & & -0.60 & & -0.46 & & -0.38 \\
\hline & & $(0.43)$ & & $(0.41)$ & & $(0.52)$ \\
\hline Observations & 258 & 258 & 258 & 258 & 258 & 258 \\
\hline \multicolumn{7}{|c|}{$\begin{array}{l}\text { Notes: District/State-religion level observations for } 86 \text { groups (Muslim or Hindu-Sikh in } 28 \\
\text { districts and } 16 \text { Princely states, in communities with at least } 4,000 \text { male individuals in 1911), } \\
\text { for three census years (1911-31). The regression includes district-religion fixed effects and } \\
\text { religion-year effects. Standard errors are clustered at the district-religion level. }{ }^{* * *} \mathrm{p}<0.01 \text {, }{ }^{* *} \\
\mathrm{p}<0.05,{ }^{*} \mathrm{p}<0.1 \text {. }\end{array}$} \\
\hline
\end{tabular}




\section{A.3.11 Summary statistics by median}

In this robustness check, I present the summary statistics for casualty rates above and below the median (instead of the the mean, as in the main text). The mean is relatively close to the median, and the baseline balance results do not change much.

Table 20: Summary statistics by median (district-religion level)

\begin{tabular}{|c|c|c|c|c|}
\hline & $\begin{array}{l}\text { Sample } \\
\text { (1) }\end{array}$ & $\begin{array}{l}\text { Lightly } \\
\text { recruited } \\
\text { (below the } \\
\text { median) } \\
(2)\end{array}$ & $\begin{array}{c}\text { Heavily } \\
\text { recruited } \\
\text { (above the } \\
\text { median) } \\
(3)\end{array}$ & $P$-value (2)-(3) \\
\hline Male literacy rate 1911 & $\begin{array}{c}0.11 \\
(0.12)\end{array}$ & $\begin{array}{c}0.11 \\
(0.12)\end{array}$ & $\begin{array}{c}0.11 \\
(0.12)\end{array}$ & 0.94 \\
\hline Male population 1911 & $\begin{array}{c}187,428 \\
(111,440)\end{array}$ & $\begin{array}{c}179,781 \\
(111,527)\end{array}$ & $\begin{array}{c}195,075 \\
(112,863)\end{array}$ & 0.61 \\
\hline Muslim dummy & $\begin{array}{c}0.50 \\
(0.50)\end{array}$ & $\begin{array}{c}0.64 \\
(0.49)\end{array}$ & $\begin{array}{c}0.36 \\
(0.49)\end{array}$ & $0.03^{* *}$ \\
\hline $\begin{array}{l}\text { Difference in literacy rate } \\
(1921-1911)\end{array}$ & $\begin{array}{l}-0.003 \\
(0.004)\end{array}$ & $\begin{array}{l}-0.005 \\
(0.036)\end{array}$ & $\begin{array}{l}-0.001 \\
(0.031)\end{array}$ & 0.70 \\
\hline $\begin{array}{l}\text { Difference in literacy rate } \\
(1931-1911)\end{array}$ & $\begin{array}{c}0.019 \\
(0.036)\end{array}$ & $\begin{array}{l}0.014 \\
(0.04)\end{array}$ & $\begin{array}{c}0.024 \\
(0.032)\end{array}$ & 0.28 \\
\hline $\begin{array}{l}\text { Casualty rate } \\
\text { (per } 100 \text { of the } 1911 \text { male } \\
\text { population) }\end{array}$ & $\begin{array}{c}0.13 \\
(0.15)\end{array}$ & $\begin{array}{c}0.02 \\
(0.02)\end{array}$ & $\begin{array}{c}0.25 \\
(0.15)\end{array}$ & $0.00^{* * *}$ \\
\hline Observations & 56 & 28 & 28 & \\
\hline \multicolumn{5}{|c|}{$\begin{array}{l}\text { Notes: District-religion level observations for } 56 \text { groups (Muslim or Hindu-Sikh, in } 28 \\
\text { districts). Heavily recruited communities have casualties above the sample median }(0.08 \\
\text { deaths per 100). The table records sample averages and standard deviations (in parentheses). } \\
\text { P-values are for a t-test of the equality of means. }{ }^{* * *} \mathrm{p}<0.01,{ }^{* *} \mathrm{p}<0.05,{ }^{*} \mathrm{p}<0.1 \text {. }\end{array}$} \\
\hline
\end{tabular}


Table 21: Summary statistics (district level)

\begin{tabular}{|c|c|c|c|c|}
\hline British Districts & $\begin{array}{l}\text { Sample } \\
(1)\end{array}$ & $\begin{array}{l}\text { Lightly } \\
\text { recruited } \\
(2)\end{array}$ & $\begin{array}{l}\text { Heavily } \\
\text { recruited } \\
(3)\end{array}$ & $\begin{array}{l}\text { P-value } \\
(3)-(2)\end{array}$ \\
\hline $\begin{array}{l}\text { Casualty rate (per } 100 \text { men in } \\
\text { 1911) }\end{array}$ & $\begin{array}{c}0.15 \\
(0.14)\end{array}$ & $\begin{array}{c}0.04 \\
(0.03)\end{array}$ & $\begin{array}{c}0.25 \\
(0.12)\end{array}$ & $<0.01^{* * *}$ \\
\hline $\begin{array}{l}\text { Recruitment rate (Leigh, 1922) } \\
\text { (in the eligible male } \\
\text { population) }\end{array}$ & $\begin{array}{l}0.13 \\
(0.10)\end{array}$ & $\begin{array}{c}0.06 \\
(0.04)\end{array}$ & $\begin{array}{r}0.20 \\
(0.10)\end{array}$ & $<0.01^{* * *}$ \\
\hline Male literacy rate 1911 & $\begin{array}{l}0.070 \\
(0.04)\end{array}$ & $\begin{array}{l}0.076 \\
(0.05)\end{array}$ & $\begin{array}{l}0.064 \\
(0.02)\end{array}$ & 0.40 \\
\hline Male population 1911 & $\begin{array}{c}379,601 \\
(125,758)\end{array}$ & $\begin{array}{c}394,722 \\
(149,581)\end{array}$ & $\begin{array}{l}364,480 \\
(99,898)\end{array}$ & 0.42 \\
\hline $\begin{array}{l}\text { Primary education spending } \\
1911 \\
\text { (Rs per male population } \\
\text { under } 20 \text { ) }\end{array}$ & $(0.13)$ & $(0.16)$ & $(0.03)$ & 0.80 \\
\hline $\begin{array}{l}\text { Primary school students } \\
\text { in } 1914 \text { (per male population } \\
\text { under 20) }\end{array}$ & $(0.02)$ & $(0.02)$ & $(0.01)$ & 0.22 \\
\hline Colony dummy & $\begin{array}{c}0.25 \\
(0.14)\end{array}$ & $\begin{array}{c}0.5 \\
(0.52)\end{array}$ & $\begin{array}{c}0.00 \\
(0.00)\end{array}$ & $<0.01^{* * *}$ \\
\hline $\begin{array}{l}\text { Fraction of males in } 1911 \text { born } \\
\text { in district of enumeration }\end{array}$ & $\begin{array}{c}0.87 \\
(0.15)\end{array}$ & $\begin{array}{c}0.81 \\
(0.19)\end{array}$ & $\begin{array}{c}0.92 \\
(0.04)\end{array}$ & $0.04^{* *}$ \\
\hline $\begin{array}{l}\text { Population density } \\
\text { (1911 male population/ha) }\end{array}$ & $\begin{array}{c}149 \\
(83.6)\end{array}$ & $\begin{array}{c}136 \\
(74.6)\end{array}$ & $\begin{array}{c}164 \\
(92.0)\end{array}$ & 0.36 \\
\hline $\begin{array}{l}\text { Fraction of Muslims } \\
\text { (in } 1911 \text { male population) }\end{array}$ & $\begin{array}{c}0.56 \\
(0.27)\end{array}$ & $\begin{array}{c}0.61 \\
(0.24)\end{array}$ & $\begin{array}{c}0.51 \\
(0.30)\end{array}$ & 0.33 \\
\hline $\begin{array}{l}\text { Fraction of Sikhs } \\
\text { (in } 1911 \text { male population) }\end{array}$ & $\begin{array}{c}0.10 \\
(0.10)\end{array}$ & $\begin{array}{c}0.09 \\
(0.08)\end{array}$ & $\begin{array}{c}0.11 \\
(0.12)\end{array}$ & 0.65 \\
\hline $\begin{array}{l}\text { Land revenues in } 1911 \\
\text { (Rs per male population) }\end{array}$ & $\begin{array}{c}2.8 \\
(0.9)\end{array}$ & $\begin{array}{c}2.7 \\
(1.0)\end{array}$ & $\begin{array}{c}2.9 \\
(0.7)\end{array}$ & 0.60 \\
\hline $\begin{array}{l}\text { Mortality rate } 1906-1910^{\dagger} \\
(\text { deaths per } 1,000)\end{array}$ & $\begin{array}{c}40.3 \\
(36.5)\end{array}$ & $\begin{array}{c}38.6 \\
(10.0)\end{array}$ & $\begin{array}{l}41.5 \\
(7.0)\end{array}$ & 0.47 \\
\hline Agricultural earners rate 1911 & $\begin{array}{c}0.36 \\
(0.06)\end{array}$ & $\begin{array}{c}0.34 \\
(0.04)\end{array}$ & $\begin{array}{c}0.37 \\
(0.06)\end{array}$ & 0.17 \\
\hline Observations & 28 & 18 & 18 & \\
\hline \multicolumn{5}{|c|}{$\begin{array}{l}\text { Notes: District level observations in } 28 \text { districts. Heavily recruited districts have casualty rates } \\
\text { above the sample median }(0.11) \text {. The table records sample averages and standard deviations } \\
\text { (in parentheses). }{ }^{\dagger} \text { This data was available for } 21 \text { districts, of which } 8 \text { are heavily recruited. } \\
\text { P-values are based on a t-test on the equality of means. }{ }^{* * *} \mathrm{p}<0.01,{ }^{* *} \mathrm{p}<0.05,{ }^{*} \mathrm{p}<0.1 .\end{array}$} \\
\hline
\end{tabular}




\section{A.3.12 Robustness to skwedness and outliers}

To address concerns that the skewed nature of the casualty distribution or outliers are driving the results, I perform two robustness checks. First, I present the main results for the square root of the casualty rate, which is more uniformly distributed than the raw casualty rates. Second, I present the main results for a "top-coded" casualty rate, in which I replace the top five casulaty rates with the value of the sixth largest casualty rate. Both robustness checks yield higher t-statistics than the main results, which suggests that outliers are not driving the effects.

Table 22: Robustness to outliers

\begin{tabular}{|c|c|c|c|c|c|c|}
\hline & \multicolumn{6}{|c|}{ Log(male literacy rate) } \\
\hline & \multicolumn{2}{|c|}{ All ages } & \multicolumn{2}{|c|}{ Over 20} & \multicolumn{2}{|c|}{ Under 20} \\
\hline & $(1)$ & $(2)$ & $(3)$ & $(4)$ & $(5)$ & (6) \\
\hline \multicolumn{7}{|l|}{ Square root of casualty } \\
\hline rate & $0.31^{* * *}$ & & $0.37^{* * *}$ & & 0.10 & \\
\hline$* 1921$ & $(0.12)$ & & $(0.11)$ & & $(0.16)$ & \\
\hline \multicolumn{7}{|l|}{ Square root of casualty } \\
\hline rate & $0.43^{* *}$ & & $0.45^{* * *}$ & & 0.29 & \\
\hline$* 1931$ & $(0.18)$ & & $(0.15)$ & & $(0.25)$ & \\
\hline Top coded casualty rate & & $0.45^{* * *}$ & & $0.54^{* * *}$ & & 0.12 \\
\hline$* 1921$ & & $(0.18)$ & & $(0.17)$ & & $(0.24)$ \\
\hline Top coded casualty rate & & $0.62^{* *}$ & & $0.65^{* * *}$ & & 0.45 \\
\hline$* 1931$ & & $(0.26)$ & & $(0.23)$ & & $(0.36)$ \\
\hline Observations & 168 & 168 & 168 & 168 & 168 & 168 \\
\hline
\end{tabular}

Notes: District-religion level observations for 56 groups (Muslim or Hindu-Sikh, in 28 districts) and for three census years (1911-31). All regressions include district-religion fixed effects and religion-year effects. Standard errors are clustered at the district-religion level. ${ }^{* * *}$ $\mathrm{p}<0.01,{ }^{* *} \mathrm{p}<0.05, * \mathrm{p}<0.1$. 


\section{A.3.13 Employment impacts}

The Census provides information on occupations at the district level. If military service boosts literacy, veterans could shift towards occupations in which they use their newly learned skills. Table 23 presents these employment impacts, but fails to find any significant impacts. As the census does not distuinguish between roles that require literacy skills within broad occupation groups, this finding may not be surprising. Also, even if veterans start working in jobs that require literacy skills, this does not necessarily mean that the number of people employed in these categories increases at the district level. It is possible that veterans just replace other groups who used to carry out these jobs.

Table 23: Effects on male occupation categories

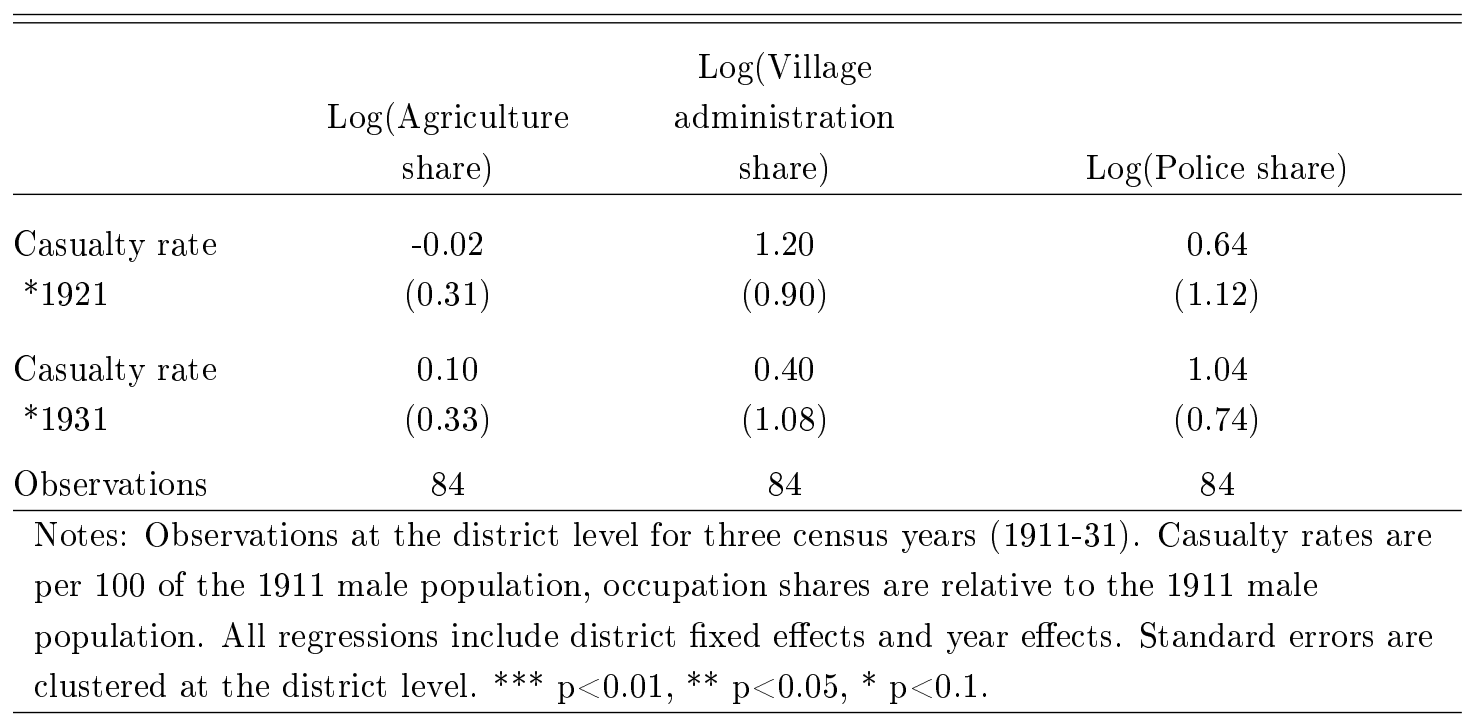

